\title{
Redox element record shows that environmental perturbations associated with the T-OAE were of longer duration than the carbon isotope record suggests - the Aubach section, SW Germany
}

\author{
Iben Winther Hougård $^{1 *}$, Jørgen A. Bojesen-Koefoed ${ }^{2}$, Madeleine L. Vickers ${ }^{1}$, \\ Clemens V. Ullmann ${ }^{3}$, Christian J. Bjerrum ${ }^{1}$, Malgorzata Rizzi ${ }^{1}$ and \\ Christoph Korte ${ }^{1}$
}

With 7 figures and 2 tables

\begin{abstract}
The Early Jurassic Toarcian Oceanic Anoxic Event (T-OAE) with its associated carbon-isotope excursion (CIE) was possibly one of the most pronounced periods of widespread oxygen deficiency in the Mesozoic ocean. The event has been extensively studied in order to understand the processes triggering the environmental perturbations and the extreme oxygen depletion in many marine basins. However, comparatively little focus has been placed on the end of the positive CIE and the stratigraphic coherent end of anoxiceuxinic conditions. In the present study, we constrain the stratigraphic extent of anoxic-euxinic conditions and define the termination of the positive CIE in the Swabo-Franconian Basin covering the Lower Toarcian strata using carbon-isotope ratios, organic matter pyrolysis and redox-sensitive element concentrations of outcrop samples from the Aubach section. Bulk organic carbon-isotope values, corrected for changes in type of organic matter using the Hydrogen Index (HI), suggest that the amplitude of the negative CIE in organic matter is as little as 3.3-3.5\%, in contrast to $4.5 \%$ change in $\delta^{13} \mathrm{C}_{\text {carb }}$ in the same section. Enrichment in redox-sensitive proxies (V/Al and DOP-T) and \%TOC suggest that environmental perturbations associated with the T-OAE continued until the upper falciferum Zone in the Aubach section. This indicates that anoxic-euxinic conditions terminated in the same stratigraphic interval in which $\delta^{13} \mathrm{C}$ values return to steady, light values at $\sim-28 \%$ (termination of positive CIE). This synchronism in the return to normal marine conditions is also observed in the southern Paris Basin, but not in the Cleveland Basin.
\end{abstract}

Key words. Toarcian Oceanic Anoxic Event, $\delta^{13} \mathrm{C}$, carbon isotope stratigraphy, redox proxies, Jurassic environment

\section{Introduction}

The Toarcian Oceanic Anoxic Event (T-OAE;

$\sim 182$ Myr ago) represents one of the most pronounced episodes of widespread ocean oxygen deficiency in the Phanerozoic, The T-OAE resulted in enhanced organic matter (OM) burial, numerous geochemical anomalies (Frimmel et al. 2004, Jenkyns 2010, Thi-

\footnotetext{
Authors' addresses:

${ }^{1}$ IGN, University of Copenhagen, Øster Voldgade 10, Copenhagen, DK; iwh@ign.ku.dk,mlv@ign.ku.dk, cjb@ign.ku.dk, malgorzatarizzi@gmail.com, korte@ign.ku.dk

2 GEUS, Øster Voldgade 10, Copenhagen, DK; jbk@geus.dk

${ }^{3}$ CSM, University of Exeter, Penryn, Cornwall TR10 9FE, UK, c.ullmann@exeter.ac.uk

* Corresponding author: iwh@ign.ku.dk
} 
bault et al. 2018), and global climate warming (Bailey et al. 2003, Jenkyns 2010, Korte et al. 2015, Ullmann et al. 2020). One of the most prominent geochemical features associated with the T-OAE is the fluctuation in the $\delta^{13} \mathrm{C}$ record. A long-lasting positive carbon isotope excursion (pCIE) (Hesselbo et al. 2000, Hermoso et al. 2009a, Hermoso et al. 2009b, Hermoso et al. 2012) is marked by a large-scale negative CIE (nCIE) (Fig. 1A) (Jenkyns et al. 2002, McArthur et al. 2008, Korte et al. 2015). Previous work has shown that the Early Toarcian nCIE commenced in the upper tenuicostatum/polymorphum Zone (ammonite biozonation) and culminated in the lower falciferum/serpentinum Zone as shown by the $\delta^{13} \mathrm{C}$ reference curve for the Early Toarcian based on published sections
(Ruebsam and Al-Husseini 2020). The nCIE has been detected in marine and terrestrial $\mathrm{OM}$ and marine carbonate from successions across Europe (Jenkyns 1988, Röhl et al. 2001, Kemp et al. 2005, Suan et al. 2008, Hermoso et al. 2009a, Hermoso et al. 2009b), N-Africa (Krencker et al. 2020), S-America (Fantasia et al. 2018a, Al-Suwaidi et al. 2010), N-America (Them et al. 2017a), Japan (Gröcke et al. 2011, Kemp et al. 2019), and Arctic Russia (Suan et al. 2011), indicating that the global carbon cycle was greatly influenced.

Ocean anoxic events have traditionally been defined on the basis of widespread deposition of laminated black shale (Jenkyns 1988, Jenkyns 2010), yet the \% TOC in a succession may be heavily influenced by

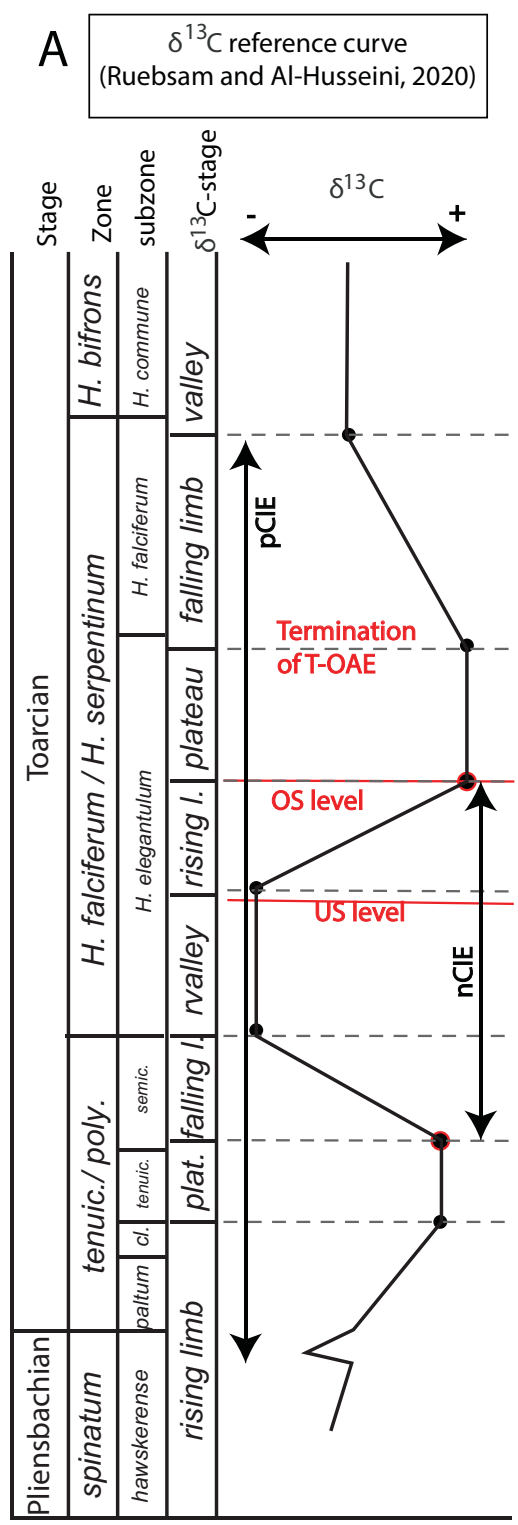

B

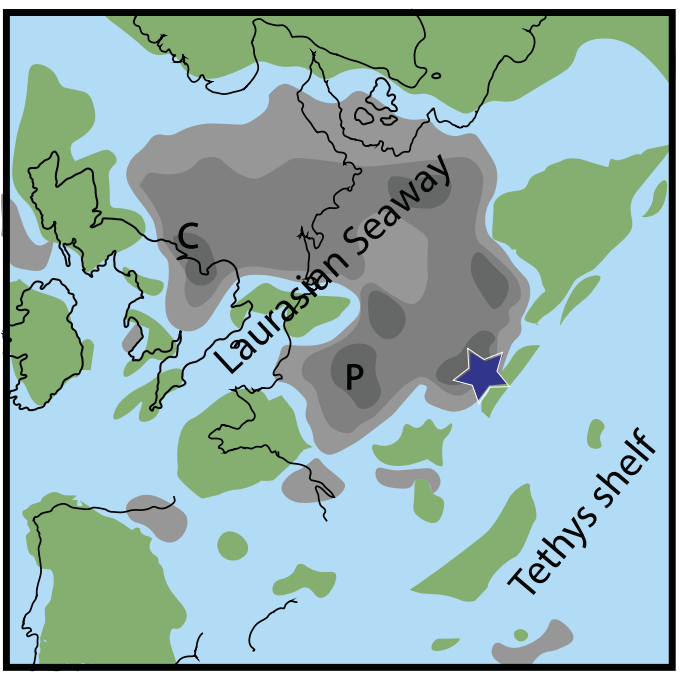

Fig. 1. A) The $\delta^{13} \mathrm{C}$ reference curve by Ruebsam and $\mathrm{Al}-$ Husseine (2020) modified to include the PliensbachianToarcian nCIE, termination of the T-OAE and end of the Toarcian pCIE. B) Paleogeographic map of the Laurasian Seaway in the Early Jurassic with the studied locality, the Aubach section (star) situated in the Swabo-Franconian Basin, Cleveland Basin: C and Paris Basin: P (modified from e.g. Ruebsam et al. 2018) Emerged landmasses (green), organic-rich sediment (grey, darker grey represent a higher \%TOC). 
local effects, and thus the understanding of the T-OAE as a global climate perturbation contrasts to a definition applicable only to a limited set of palaeoenvironments. Such a definition is therefore not optimal for global considerations (Wignall et al. 2005) as global climate change likely transcended such restricted definitions. Now, generally, the T-OAE is defined by patterns in the coeval $\mathrm{C}$-isotope curve, e.g., the onset limb of the positive the $\delta^{13} \mathrm{C}$ perturbation caused by the widespread burial of organic matter (cf. Jenkyns 2010) (Fig. 1A). This definition sets the beginning of the OAE where $\delta^{13} \mathrm{C}$ values start to change and the end at the climax of the positive $\delta^{13} \mathrm{C}$ excursion (pCIE) values decrease. The Toarcian pCIE is interrupted by the nCIE (e. g., Hermoso et al. 2009), which can prove it challenging to recognize its beginning.

When the end of the T-OAE is based on the stratigraphic datum where the most positive $\delta^{13} \mathrm{C}$ values are reached, it terminates in the early serpentium/falciferum Zone (Hesselbo 2008, Hermoso et al. 2013). Yet, previous studies show that black shale formation was not restricted to the lower falciferum Zone in the Swabo-Franconian Basin (Fantasia et al. 2018a, Röhl and Schmid-Röhl 2005, Van de Schootbrugge et al. 2013). Furthermore, other geochemical proxies indicate that environmental and climatic conditions were still perturbed after the nCIE, far from having returned to pre-excursion levels in many sections. Organic matter characteristics, trace element and biomarker data from the nearby Dotternhausen section (Schouten et al. 2000, Schwark and Frimmel 2004, Suan et al. 2015, Röhl et al. 2001, Them et al. 2018, Dickson et al. 2017) and Swiss successions (Fantasia et al. 2018b, Montero-Serrano et al. 2015) show that intense oxygen-depletion continued in the SwaboFranconian Basin and that redox conditions became more oxidized on the continental margin after the carbon isotope anomaly. In the Paris Basin (France) and the Cleveland Basin (UK) enrichment in redoxsensitive elements indicate that anoxia also continued beyond the nCIE and lasted into the upper falciferum Zone (Hermoso et al. 2013, Thibault et al. 2018). This all states well that the environmental perturbation of the T-OAE played out differently from basin to basin. However, comparatively little focus has been placed on how the continuation of anoxia and high \% TOC correlate with the return to steady light $\delta^{13} \mathrm{C}$ values at the end of the Toarcian pCIE.

In the present study, we investigate the evolution of the seawater chemistry through the Early Toarcian in the Aubach section (Swabo-Franconian Basin, SW
Germany) in relation to the stratigraphic extent of the Toarcian nCIE and the termination of the Toarcian pCIE by combining $\delta^{13} \mathrm{C}$ and TOC $(w t \%)$ with redoxsensitive element concentrations using new high-resolution geochemical data. The evaluation of the nCIE and termination at the peak pCIE is based on $\delta^{13} \mathrm{C}_{\mathrm{org}}$ and $\delta^{13} \mathrm{C}_{\text {carb }}$, as well as on changes in OM sources. The degree of pyritization based on total Fe (DOP-T) and V/Al, among various geochemical proxies for anoxic/ euxinic conditions, have been selected to assess the stratigraphic extent of anoxia in Aubach.

\section{Geological setting}

The Aubach section is located in the Wutach river area (Baden-Württemberg, SW Germany) between the Swabian Alps and the Black Forest. The outcrop succession consists of Lower Jurassic sediments deposited in the shallow-marine Swabo-Franconian Basin that was part of the Laurasian Seaway, which connected the Tethys to the Boreal Ocean (Fig. 1B) (Bjerrum et al. 2001). In the Early Jurassic, this seaway bordered the northwestern part of the Tethyan epicontinental shelf in the South and the Boreal Sea in North (Fig. 1; Bailey et al. 2003).

The section consists of marls with limestone horizons in the Pliensbachian spinatum Zone (Fig. 2). The Lower Toarcian interval of the section comprises bioturbated light-grey marl constituting the Blaugraue Mergel and Aschgraue Mergel interbedded by two laminated shale beds in the semicelatum Zone. The lower and middle falciferum/serpentinum Zone consist of dark laminated shales characterized by distinct wavy to lenticular microlamination with two thick limestone horizons. Benthic fauna is absent (Riegraf et al. 1984). A predominance of dark claystone, black shale and condensation/discontinuity surfaces demonstrate a general transgressive trend in these Lower Jurassic strata (Pienkowski et al. 2008).

The Lower Jurassic strata of the Aubach section became exposed during the development of the west European rift system in the Oligocene resulting in the uplift of the Black Forest massif (Ziegler 1992, Demoulin et al. 1998). Rivers subsequently cut deep and narrow incisions during the Quaternary, and recent land-slides have served to produce excellent exposures of the Lower Jurassic succession in the investigated region (Demoulin et al. 1998). 


\section{Material and Methods}

\subsection{Sampling}

Biostratigraphic subdivision for the Aubach outcrop section is taken from Riegraf et al. (1984), which is the most recent zonation available for this section. A total of 123 bulk-rock samples were collected from uppermost Pliensbachian to Lower Toarcian sediments with a resolution of $\sim 20 \mathrm{~cm}$ in the uppermost Pliensbachian, $5-10 \mathrm{~cm}$ in the lower Toarcian and $20-100 \mathrm{~cm}$ in the higher elegans subzone. During sampling, the outermost weathered surface sediment was removed, and only fresh material was collected.

\subsection{Stable isotopes}

Stable isotope analysis was performed on bulk rock samples using an IsoPrime triple collector Isotope Ratio Mass spectrometer at the Department of Geosciences and Natural Resource Management at the University of Copenhagen (IGN). A total of 72 and 160 samples were analysed to determine $\delta^{13} \mathrm{C}_{\text {carb }} /$ $\delta^{18} \mathrm{O}_{\text {carb }}$ and $\delta^{13} \mathrm{C}_{\text {org }}$, respectively.

Crushed sample material, equivalent to $0.6 \mathrm{mg}$ carbonate, was placed into $3.5 \mathrm{ml}$ glass Labco vials and sealed with plastic lids for $\delta^{13} \mathrm{C}_{\text {carb }}$ and $\delta^{18} \mathrm{O}_{\text {carb }}$ analysis. Vials were flushed with helium to remove atmospheric gasses and subsequently reacted with nominally anhydrous phosphoric acid at $70^{\circ} \mathrm{C}$ for 90 min. The measured ${ }^{13} \mathrm{C} /{ }^{12} \mathrm{C}$ and ${ }^{18} \mathrm{O} /{ }^{16} \mathrm{O}$ ratios were normalized against a $\mathrm{CO}_{2}$ reference gas. The reproducibility of the analyses was $0.12 \%$ for $\delta^{13} \mathrm{C}$ $(2 \sigma)$ and $0.16 \%$ for $\delta^{18} \mathrm{O}(2 \sigma)$ based on 15 standards to 45 samples in each batch of analyses. Isotope ratios were corrected with the in-house reference material LEO $\left(\delta^{13} \mathrm{C}=+1.96 \%\right.$; $\delta^{18} \mathrm{O}=-1.93 \%$; see Ullmann et al. 2013).

For organic $\delta^{13} \mathrm{C}$ analysis, powdered samples were decarbonated by placing the sample in a $50 \mathrm{ml}$ polypropylene centrifuge tube and treating with $10 \% \mathrm{HCl}$ for 1 hour at $60^{\circ} \mathrm{C}$. The samples were then rinsed with demineralized water, centrifuged, and rinsed again until neutrality was reached (following the method of Gröcke et al. 1999). These decarbonated samples were then freeze-dried to remove potential liquids. Decarbonated bulk rock material with a weight equivalent to $60 \mu \mathrm{g}$ organic carbon was packed in tin capsules for $\delta^{13} \mathrm{C}_{\text {org }}$ analysis. Samples were fluxed in an oven heated to $1100^{\circ} \mathrm{C}$, where oxygen was added to react the $\mathrm{OM}$ to $\mathrm{CO}_{2}$. The measured ${ }^{13} \mathrm{C} /{ }^{12} \mathrm{C}$ ratios were corrected against the in-house reference AKsill_9 $\left(\delta^{13} \mathrm{C}=-25.30 \% ; 18\right.$ standards to 57 samples). Carbon-isotope ratio reproducibility was found to be $0.07 \%$ o ( $2 \sigma$ of repeat measurements of the lab standard).

The in-house reference material LEO $\left(\delta^{13} \mathrm{C} 1.96 \%\right.$ and $\delta^{18} \mathrm{O}-1.93 \%$ ) and AKsill_9 $(-25.30 \%)$ are calibrated to the international reference materials NBS-18 and NBS-19 and USGS-24 respectively, ensuring accurate determination of isotope ratios.

\subsection{Organic geochemistry}

Bulk-rock samples were crushed using a mill and sieved to grain sizes smaller than $\sim 250 \mu \mathrm{m}$. Organic matter pyrolysis was carried out on 70 samples of $100 \mathrm{mg}$ size at the Department of Reservoir Geology, Geological Survey of Denmark and Greenland (GEUS) using a HAWK instrument (Wildcat Technologies, USA). This instrument was calibrated using the IFP 160000 standard reference material to yield results similar and comparable to those obtained by the Rock-Eval 6 instrument. Total Organic Carbon contents (TOC wt $\%$ ), Hydrogen Index (HI) and Oxygen Index (OI) were determined.

The calcium carbonate concentrations of 123 samples were determined by calculating the loss of weight after decarbonisation. A subset of 93 of these decarbonated samples were analysed for TOC and Total Sulphur (TS) using an Eltra CS 500 Analyzer at IGN.

\subsection{X-ray fluorescence (XRF) analysis}

$\mathrm{XRF}$ analysis was undertaken to determine the concentrations of redox-sensitive elements. XRF measurements were performed on 120 powdered samples stored in plastic containers covered with 0.016 millimetre thick polypropylene film following Lenniger et al. (2014). Element concentrations of the samples were determined using a hand-held NitonTmX13tGoldd+ XRF device ( $h h-\mathrm{XRF}$ ) equipped with an Ag anode (measurements at 6-50 kV and 0-200 $\mu \mathrm{A} \max$ ), and inductively coupled plasma mass spectrometry (ICPMS) at GEUS. The geochemical composition of 120 samples was determined based on three replicates measured for 100 seconds using the 'test all geo filter' program on the $h h-\mathrm{XRF}$ that allows determination of 32 elements. Correction-factors for $h h-\mathrm{XRF}$ data against ICP-MS measurements and sulphur concentration to \% TS data, are all tightly constrained (Table 1). 
Table 1. Correction-factors for hh-XRF data against ICP-MS measurements and sulphur concentration to \%TS data.

\begin{tabular}{lllllll}
\hline Element & Slope (a) & Intercept (b) & $\mathrm{r}^{2}$ & $\mathrm{p}$-values $<0.01$ & $\mathrm{~N}$ & $\mathrm{r}$ \\
\hline $\mathrm{Fe}(\mathrm{ppm})$ & 0.9718 & 3616 & 0.9836 & yes & 10 & 0.99 \\
$\mathrm{~V}(\mathrm{ppm})$ & 1.2318 & -17.97 & 0.8959 & yes & 9 & 0.95 \\
$\mathrm{Al}(\mathrm{ppm})$ & 1.8498 & -7802.4 & 0.9927 & yes & 10 & 1.00 \\
$\mathrm{~S}(\mathrm{ppm})$ & 0.8804 & 3401 & 0.8435 & yes & 62 & 0.92 \\
\hline
\end{tabular}

\section{Results}

\subsection{Stable isotopes}

Organic $\delta^{13} \mathrm{C}$ data vary between $-24.5 \%$ and $-32.4 \%$ (Fig. 2). Two short-term negative excursion of $\sim 2.3 \%$ are observed at the Pliensbachian-Toarcian boundary. Marked negative excursions occur coeval with the black shales in the semicelatum Zone $(\sim 4 \%$ in the Tafelfleins and $\sim 2 \%$ in the two Seegrasschiefers shales). The pronounced and well-known Early Toarcian nCIE commences in the uppermost semicelatum Zone and is here characterized by four steps (Fig. 2). This CIE culminates in the exaratum subzone reaching a total decrease of $6.3 \%$ (lowest value $-32.4 \%$ ) after which $\delta^{13} \mathrm{C}_{\text {org }}$ values steadily increase. $\delta^{13} \mathrm{C}_{\text {org }}$ values reach the plateau of the Toarcian pCIE of $-26.6 \%$ to $-25.6 \%$ in the upper part of the elegans subzone and decrease to $\sim-28 \%$ in the lower part of the falciferum subzone, marking the end of the Toarcian pCIE (Fig. 2).

The $\delta^{13} \mathrm{C}_{\text {carb }}$ values range from $-6.5 \%$ to $+1.7 \%$. The $\delta^{13} \mathrm{C}_{\text {carb }}$ profile fluctuates around $0 \%$ in the upper spinatum Zone and records minimum values of $-2.5 \%$ in $\mathrm{CaCO}_{3}$-rich beds occurring immediately below the Pliensbachian-Toarcian transition (Fig. 2). In the lower semicelatum Zone, $\delta^{13} \mathrm{C}$ values increases to $\sim 0.6 \%$ and further to $\sim 1.3 \%$, where a significant drop of $4.5 \%$ interrupts the positive trend. The $\delta^{13} \mathrm{C}_{\text {carb }}$ minimum values of $\sim-3.2 \%$ and $\sim-2 \%$ in the exaratum subzone occur just below and above the Unterer Stein, respectively (Fig. 2). Very light $(\sim-6.5 \%) \delta^{13} \mathrm{C}_{\text {carb }}$ values occur in the middle of the Unterer Stein limestone bed and record an isotope fluctuation of $7.8 \%$ in amplitude (Fig. 1S). These extremely light $\delta^{13} \mathrm{C}_{\text {carb }}$ values of the limestone are regarded as anomalies and have been excluded from Fig. 2 .

The $\delta^{18} \mathrm{O}_{\text {carb }}$ values decrease generally from $\sim-5.3 \%$ o to $\sim 6.8 \%$ across the full section and display high variability in the Unterer Stein ranging from $-8.0 \%$ to $-3.8 \%$ o (Fig. $1 \mathrm{~S}$ ).

\subsection{Organic matter}

All samples show $\mathrm{T}_{\max }$ of $420-435^{\circ} \mathrm{C}$ (Table S2) corresponding to a level of thermal maturity just below the oil window (435-470 ${ }^{\circ} \mathrm{C}$ ) (Hunt 1996). Organic matter types have been classified using the Van Krevelen-type diagram after Hunt (1996); HI as a function of OI (mg HC/g TOC; Fig. 3). Marl and carbonate layers of the spinatum Zone and semicelatum Zone include kerogen type III with low $\mathrm{HI}(<150 \mathrm{mg} \mathrm{HC} / \mathrm{g}$ TOC) and high OI values (25-185 mg CO $2 /$ g) (Figs. 2 and 3). The OM of the two Seegrasschiefer shales and the Tafelfleins shale (semicelatum Zone) mainly contain Type II kerogen (300-600 mg HC/g TOC), and shales of the lower part of the falciferum Zone contain a mix of kerogen Type I and II with high HI (300-830 mg HC/g TOC) and low OI values $(<80 \mathrm{mg} \mathrm{CO} / \mathrm{g}$ TOC). Previous studies have established the marine origin of the Lower Toarcian strata in SW Germany (Küspert 1982, Moldowan et al. 1986, Schouten et al. 2000, Röhl et al. 2001, Frimmel et al. 2004) where kerogen I (HI >600) therefore indicates marine algae. Kerogen Type II is derived from marine plankton and kerogen Type III from oxygenated marine plants. Type III kerogen samples all display low TOC $(0.5-1 \mathrm{wt} \%)$, whereas Type I-II kerogen samples range from $5-14 \mathrm{wt} \%$ TOC with the highest TOC in the Tafelfleins shale $(13 \mathrm{wt} \%)$ and during the Early Toarcian nCIE (up to $\sim 14 \mathrm{wt} \%$ ). Above the nCIE, TOC decreases to 5-7 $\mathrm{wt} \%$ and further to $4-5 \mathrm{wt} \%$, coinciding with $\delta^{13} \mathrm{C}_{\mathrm{org}}$ value stabilizing at $\sim-28 \%$ in the upper falciferum Zone (Fig. 2).

To test whether the changing source or maturity of $\mathrm{OM}$ affected the $\delta^{13} \mathrm{C}_{\text {org }}$ data, Spearman's rank correlation was used to assess the data $\left(\delta^{13} \mathrm{C}_{\text {org }}\right.$ vs $\mathrm{T}_{\text {max }}$ : $\rho=0.41, p<0.01, n=70$ ) (Table 2). The data was assessed as a whole, and also subdivided into preexcursion (pre-CIE samples originating from the spinatum to the upper semicelatum Zone) and non-excursion (all samples outside the falciferum zone), as the 

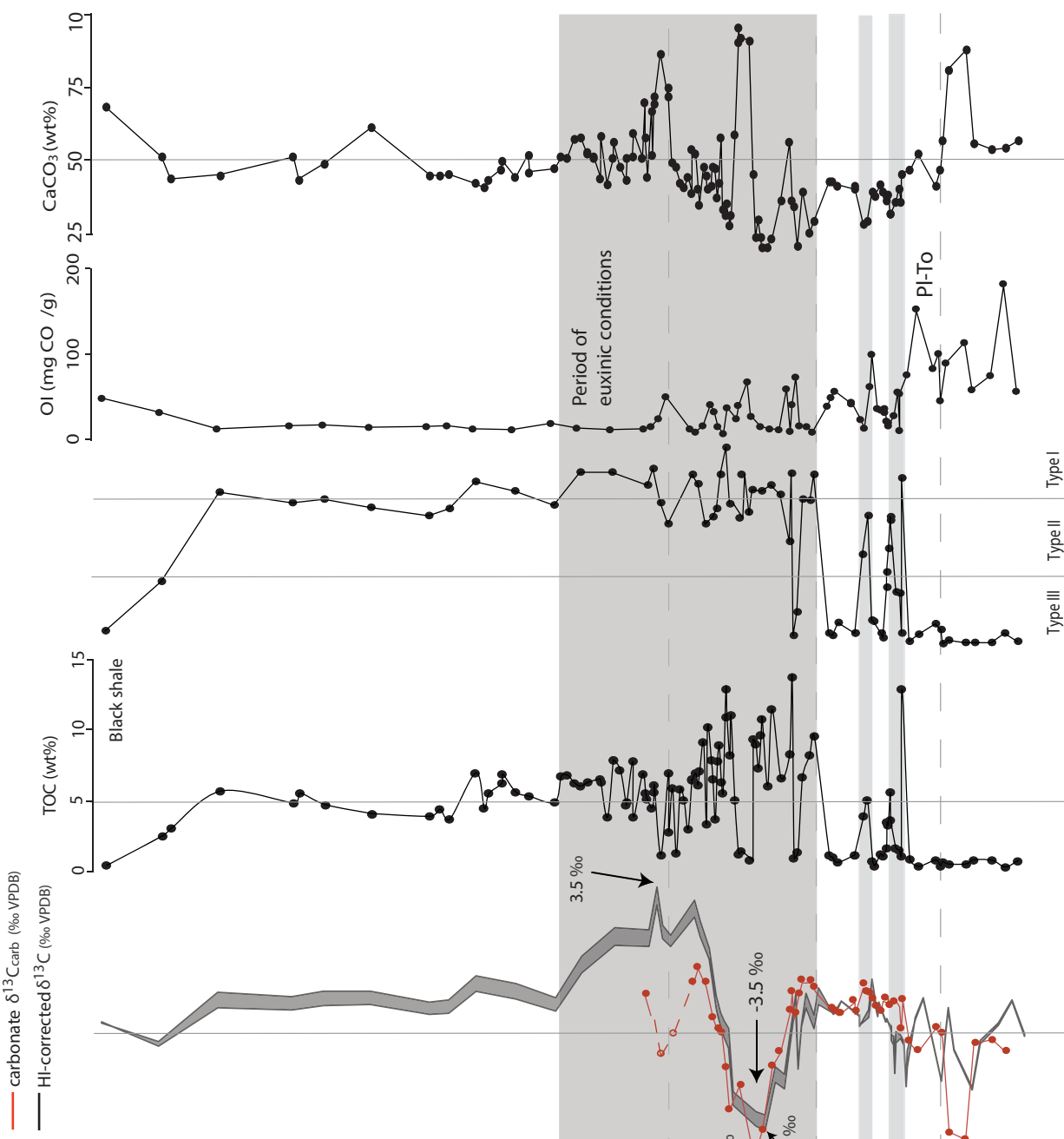

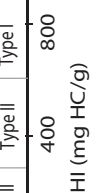
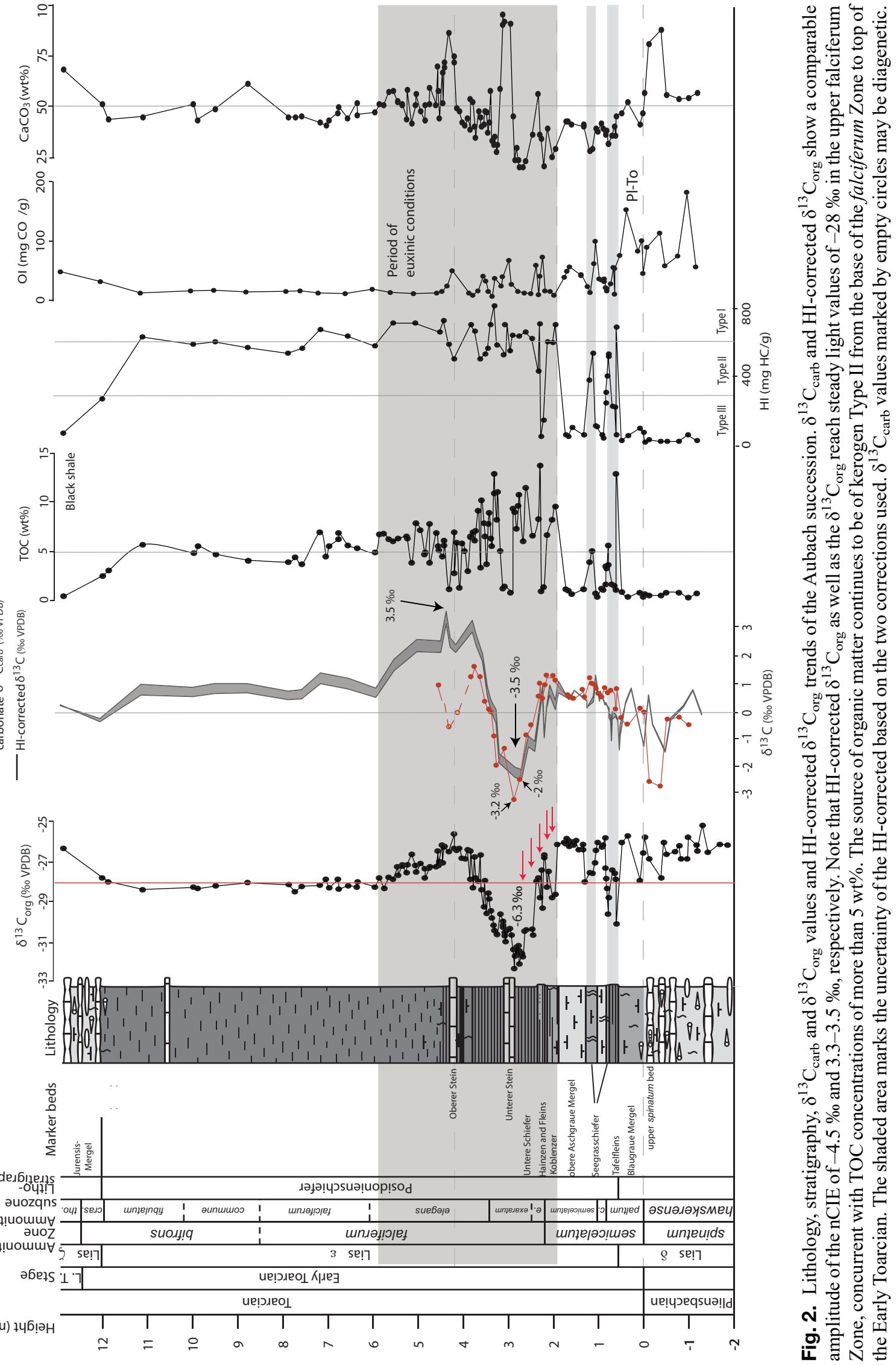


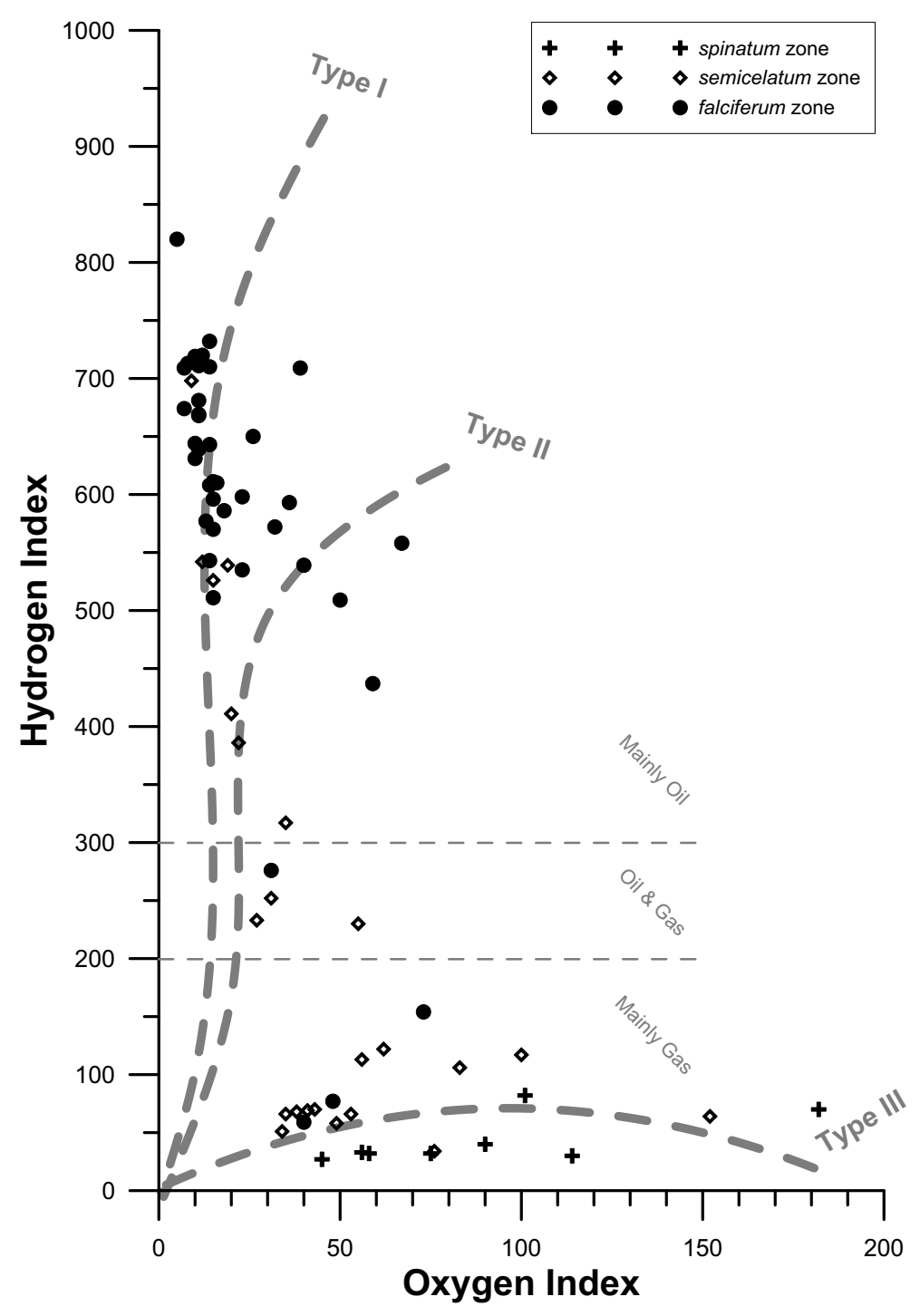

Fig. 3. Van Krevelen-type diagram after Hunt (1996); HI as a function of OI (mg HC/g TOC) for the Aubach section. The samples can be roughly grouped in two: (1) Samples of Type III kerogen from the limestone bed spinatum bed and the marly layers in the spinatum and semicelatum Zone, and (2) samples of Type I-II kerogen are from the shales in the semicelatum Zone and the falciferum Zone. spinatum Zone (plus), semicelatum Zone (diamond) and falciferum Zone (dot).

effect of OM source on $\delta^{13} \mathrm{C}$ may be different across the excursion, as demonstrated by Lenninger et al. (2014) and Suan et al. (2015). As a whole, the HI values (an analogue for OM source) showed a moderate but significant relationship to $\delta^{13} \mathrm{C}(\rho=-0.64$, $\mathrm{p}<0.01, r^{2}=0.42, \mathrm{n}=70$ ). However, excluding the CIE data, the pre-CIE data and data outside the falciferum Zone show a significant, moderate to strong correlation between $\mathrm{HI}$ and $\delta^{13} \mathrm{C}\left(\rho=0.57, \mathrm{p}<0.01, r^{2}=0.68, \mathrm{n}=31\right.$ and $\rho=0.70, \mathrm{p}<0.01, r^{2}=0.68, \mathrm{n}=37$, respectively) (Table 2).

The significant moderate/strong correlation between $\mathrm{HI}$ and $\delta^{13} \mathrm{C}$ in the data (excluding the CIE interval) indicates that the $\delta^{13} \mathrm{C}_{\text {org }}$ signal is influenced by OM source (e.g. Tyson 1995). Lenniger et al. (2014), and Suan et al. (2015) developed a correction that compensates for fluctuations in $\delta^{13} \mathrm{C}_{\text {org }}$ caused by
Table 2. Spearman's Rank correlation, slope (a) and intercept (b) of the linear relation between $\mathrm{HI}$ and $\delta^{13} \mathrm{C}_{\text {org }}$.

\begin{tabular}{llll}
\hline & Pre-CIE & All data & Outside falc. Z. \\
\hline$n$ & 31 & 70 & 37 \\
$\rho$ & -0.57 & -0.64 & -0.70 \\
$p<0.01$ & yes & yes & yes \\
$r^{2}$ & 0.68 & 0.42 & 0.68 \\
$\mathrm{a}$ & 0.005 & 0.004 & 0.004 \\
$\mathrm{~b}$ & -26.22 & -26.14 & -26.34 \\
CIE amplitude & $-3.3 \%$ & $-5.58 \% 0$ & $-3.5 \%$ \\
\hline
\end{tabular}

changes in OM type through establishing the background of $\mathrm{HI}$ and $\delta^{13} \mathrm{C}_{\text {org }}$ in the basin, via the nonexcursion $\mathrm{HI}-\delta^{13} \mathrm{C}$ linear relationship (Fig. 4, Table 2). We estimated the relationship for the Aubach section 


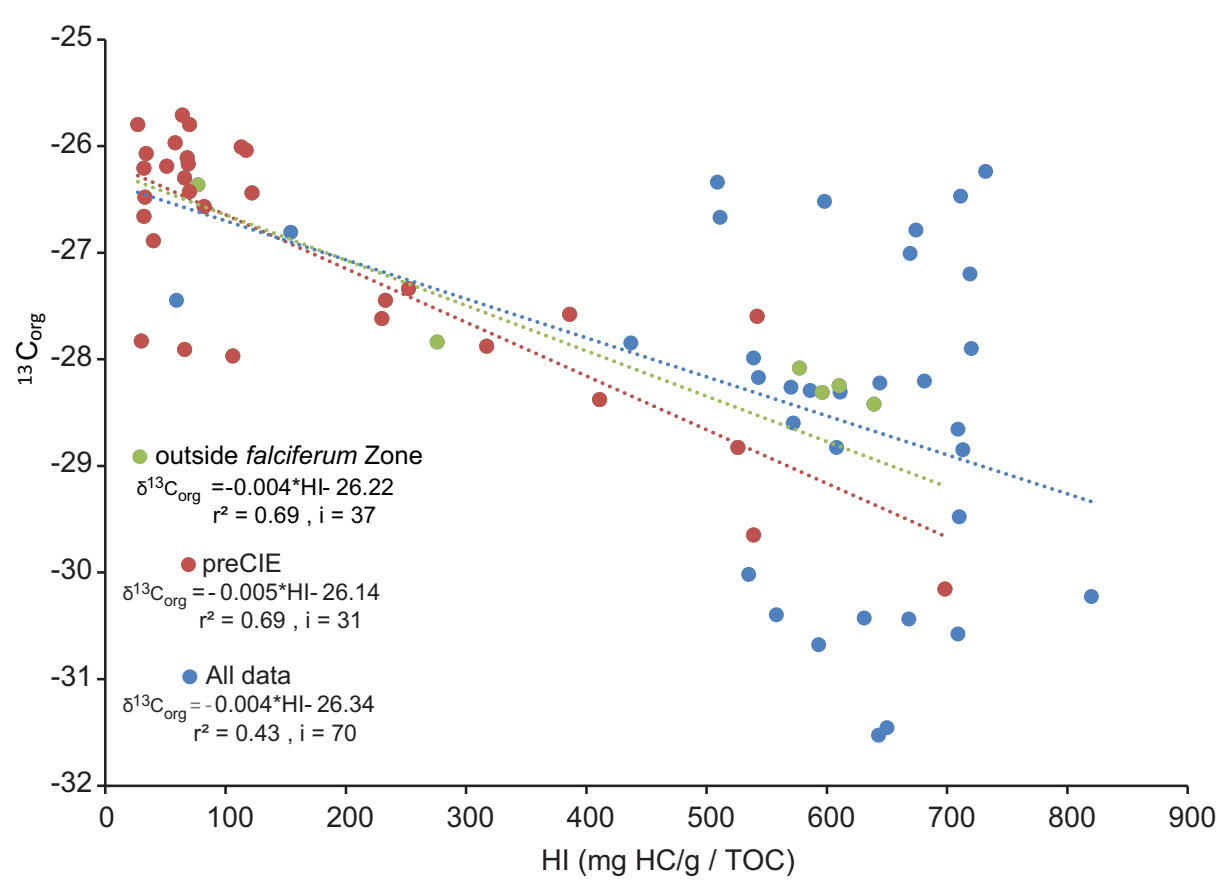

Fig. 4. The Hydrogen Index (HI)-correction of $\delta^{13} \mathrm{C}_{\text {org }}$ accounts for changes in organic matter in the Early Toarcian. The linear relation between $\mathrm{HI}$ and $\delta^{13} \mathrm{C}_{\text {org }}$ of pre-CIE samples (red), samples outside falciferum Zone (green) and all samples including the CIE. Our HI-correction is based on $\delta^{13} \mathrm{C}_{\mathrm{org}}$ as a function of HI, based on samples pre-CIE and samples outside the falciferum Zone.

and applied the resulting correction to our $\delta^{13} \mathrm{C}$ data. The outcome is a reduction in the magnitude of the nCIE from $6.3 \%$ resulting in a negative $\delta^{13} \mathrm{C}$ excursion of only 3.3-3.5\% (Fig. 2). After correction the pCIE reach a maximum $\delta^{13} \mathrm{C}_{\text {org }}$ values of $-25.6 \%$ corresponds to an increase of HI-corrected $\delta^{13} \mathrm{C}_{\text {org }}$ to $+3.5 \%$.

\subsection{Element data}

\subsubsection{Vanadium}

The vanadium concentration varies over the investigated section from below the detection limit $(<3 \mathrm{ppm})$ to $270 \mu \mathrm{g} / \mathrm{g}$ (Fig. 5). The V-enrichment is determined relative to average shale composition $(\mathrm{V}=130 \mathrm{ppm}$ and $\mathrm{V} / \mathrm{Al}=14.8 \mu \mathrm{g} / \mathrm{g} / \mathrm{wt} \%$ ) (Wedepohl 1971). Vanadium content is near or below the detection limit in the limestone beds (upper spinatum bed, Unterer Stein, Oberer Stein). V-enrichment occurs in the Tafelfleins and Seegrasschiefer shales (semicelatum Zone) and from the first step of the negative CIE in the upper semicelatum Zone. In the falciferum Zone, the V/Al ratio increases to $\sim 36$ and gradually declines to $\sim 10$ above the Oberer Stein, coinciding with the disap- pearance of laminated black shale. A significant Venrichment of $\mathrm{V} / \mathrm{Al}$ ratios up to $\sim 37$ is found in the elegans subzone.

\subsubsection{Sulphur concentration and DOP-T $(\mathrm{S} / \mathrm{Fe})$}

The sulphur concentration varies in the succession from $\sim 1 \mathrm{wt} \%$ to $4.5 \mathrm{wt} \%$ (Fig. 5). Sulphur concentrations of $>2 \mathrm{wt} \%$ only occur in the black shales in the semicelatum Zone, and coincide with high \%TOC. $\mathrm{S} / \mathrm{Fe}$ is referred to as degree of pyritization based on total $\mathrm{Fe}$ (DOP-T), which has been proposed as a simple, good indicator for redox conditions during deposition (Algeo and Maynard 2008, Berner et al. 2013). DOP-T $0-0.25$ indicates oxic, $0.25-0.50$ indicates suboxic-dysoxic conditions, and DOP-T $>0.50$ corresponds to anoxic-euxinic conditions (Algeo and Maynard 2004). DOP-T values have been excluded in the dataset where TOC $<0.5 \mathrm{wt} \%$ (Algeo and Maynard 2008). DOP-T of $0.25-0.50$ is thought to indicate dysoxic conditions in the spinatum and semicelatum zones, while DOP-T of $0.60-0.70$ reflects anoxic-euxinic conditions in the semicelatum Zone black shales. DOP-T increases significantly with the initiation of the Early Toarcian nCIE and remains between 


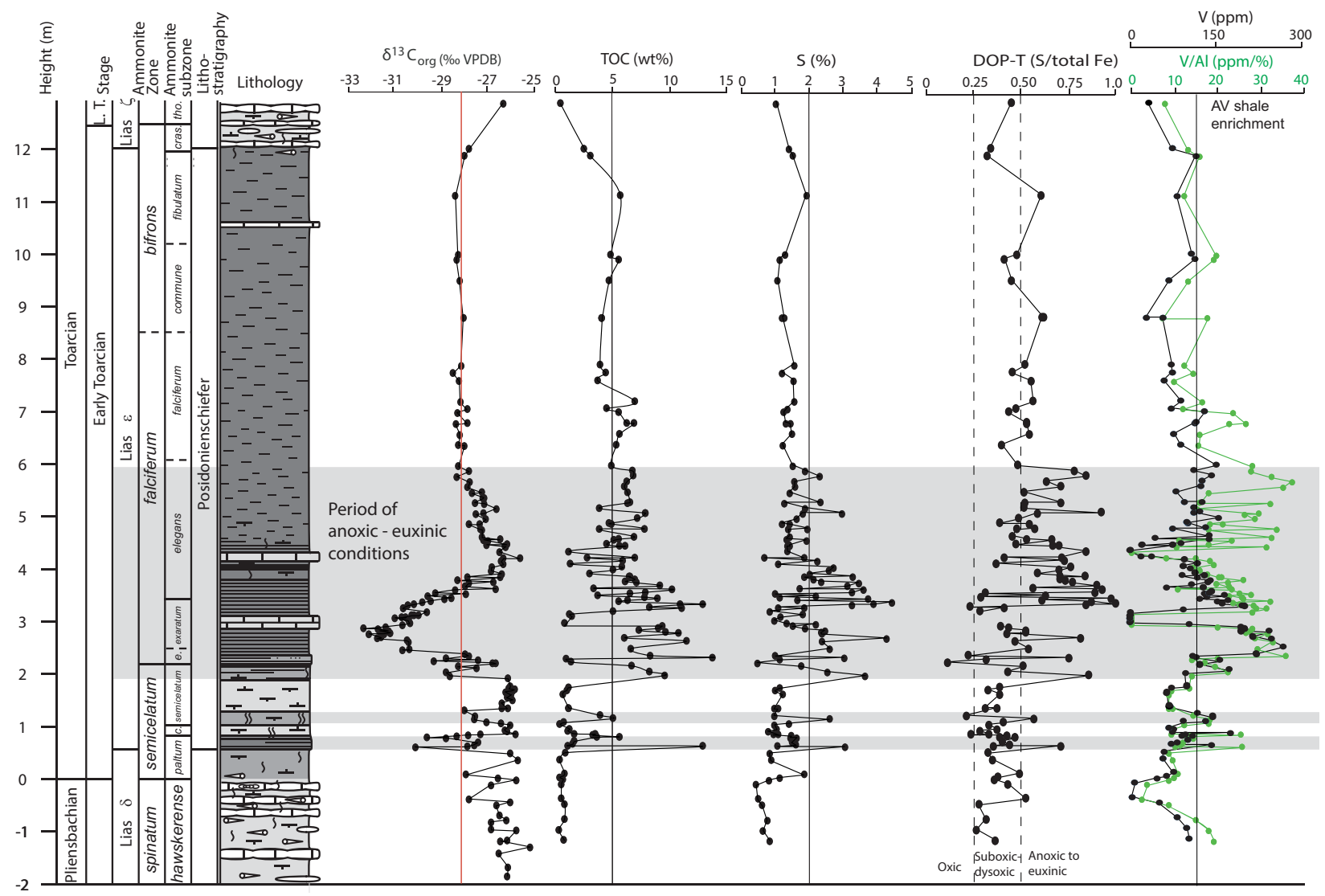

Fig. 5. Redox-sensitive elements (\%S, DOP-T and $\mathrm{V} / \mathrm{Al})$ and $\mathrm{TOC}$ concentrations. $\% \mathrm{~S}, \mathrm{DOP}-\mathrm{T}$ and $\mathrm{V} / \mathrm{Al}$ are elevated from the initiation of the nCIE until the elegans-falciferum Subzone transition marking the period of anoxic-euxinic conditions in the Aubach section, concurrent with TOC $>5 \mathrm{wt} \%$. Note that the end of anoxic-euxinic conditions is synchronous with where $\delta^{13} \mathrm{C}_{\text {org }}$ stabilizes at $-28 \%$. DOP-T have been excluded where TOC $<0.5 \mathrm{wt} \%$.

0.50 and 1 until the elegans-falciferum subzone boundary, and fluctuates around 0.50 up to the top of the investigated interval, indicating slightly improved oxygen availability.

\section{Discussion}

\subsection{The Toarcian $\delta^{13} \mathrm{C}$ record in the Swabo-Franconian Basin}

The trends in $\delta^{13} \mathrm{C}_{\text {carb }}$ and $\delta^{13} \mathrm{C}_{\mathrm{org}}$ co-vary throughout the succession indicating that an environmental imprint on the carbon isotope signal is dominant in both carbonate and organic matter. The Toarcian $\delta^{13} \mathrm{C}$ record of the Aubach section has been correlated to the $\delta^{13} \mathrm{C}$ reference curve by Ruebsam and Al-Husseini (2020) (Fig. 6), in order to define the stratigraphic extent of the Toarcian nCIE and pCIE in Aubach based on a compilation of $\delta^{13} \mathrm{C}_{\mathrm{org}}, \delta^{13} \mathrm{C}_{\text {carb }}$ and HIcorrected $\delta^{13} \mathrm{C}$ (Fig. 6). The correlation shows the onset of the nCIE in the uppermost part of the semicelatum Zone, where $\delta^{13} \mathrm{C}$ values start to decrease in four to five abrupt steps, culminating in the lower exaratum subzone (HI-correction of $\delta^{13} \mathrm{C}_{\text {org }}$ removes a step). The nCIE terminates below the Oberer Stein in the lower elegans subzone, where $\delta^{13} \mathrm{C}$ values reach a plateau.

\subsubsection{The positive CIE}

The Toarcian pCIE is interrupted by the nCIE (e.g., Hermoso et al. 2009), which can make it challenging to recognize its beginning. In Aubach, the $\delta^{13} \mathrm{C}_{\text {carb }}$ record increases to $\sim 0.6 \%$ with the first occurrence of black shale in the semicelatum Zone and further to $+1.3 \%$ by the initiation of long-term black-shale deposition in the upper semicelatum Zone (Fig. 2). One of these 


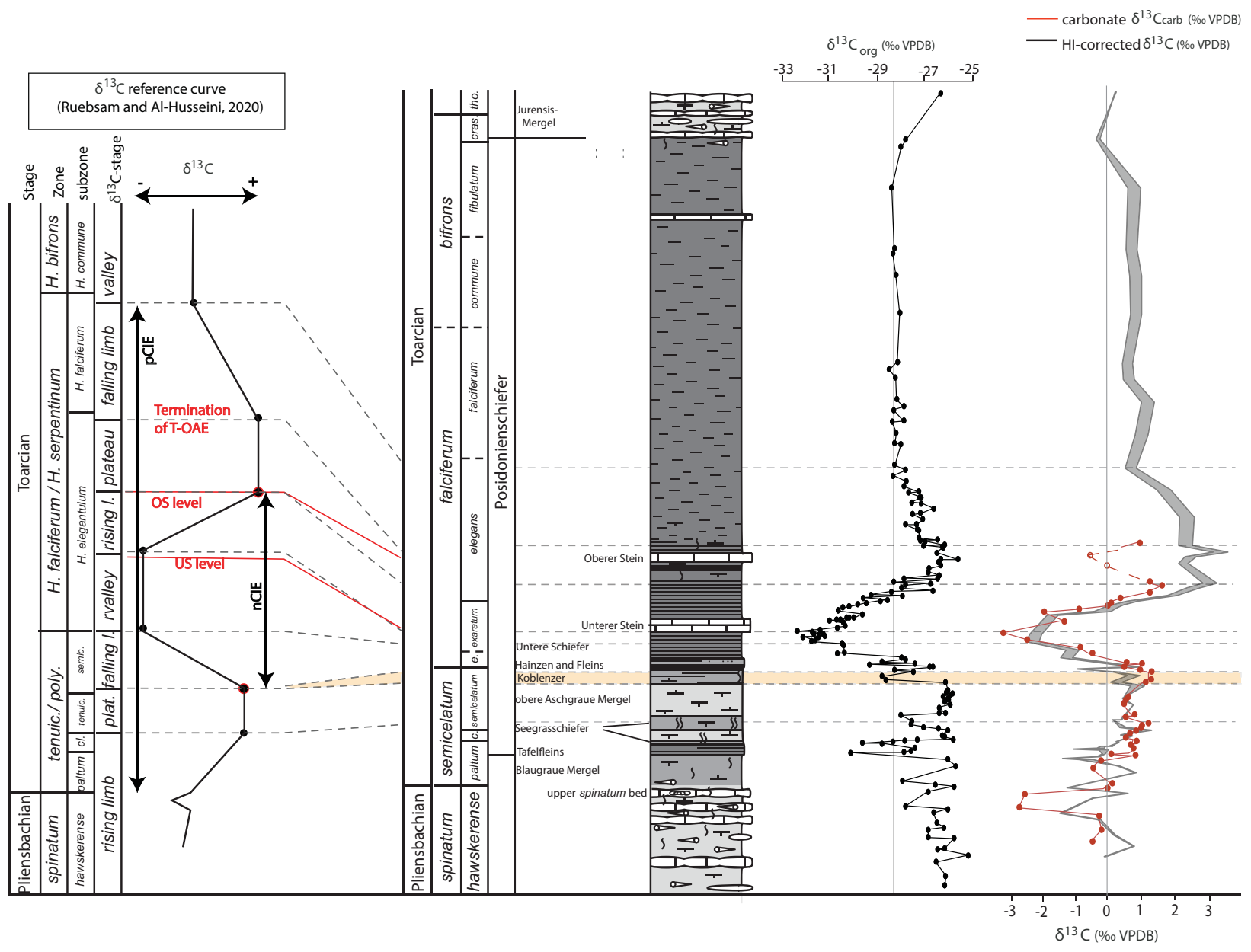

Fig. 6. The $\delta^{13} \mathrm{C}$ profile of Aubach correlated to the $\delta^{13} \mathrm{C}$ reference curve by Ruebsam and Al-Husseini (2020) to detemine the stratigraphic extent of the Toarcian nCIE and pCIE. Note that the termination of the Toarcian pCIE has been set in the upper falciferum Zone $\delta^{13} \mathrm{C}_{\mathrm{org}}$, stabilizing at $-28 \%$. The beginning of the Toarcian pCIE has not been determined.

increases in $\delta^{13} \mathrm{C}_{\text {carb }}$ values may mark the beginning of the Toarcian pCIE. Hermoso et al. (2013) argued that the Toarcian pCIE initiated at the Pliensbachian-Toarcian boundary, based on increasing $\delta^{13} \mathrm{C}_{\text {carb values in }}$ the Paris Basin (Fig. 7). Thallium isotopes from Alberta (Canada) support this, showing evidence for global marine deoxygenation of ocean water beginning at the Pliensbachian-Toarcian boundary (Them et al. 2018). Alternatively, the beginning of the Toarcian pCIE may occur already in the late Pliensbachian period as suggested by previous work (e. g. Ruebsam and Al Husseini 2020).

The Toarcian pCIE culminates in a plateau at $\delta^{13} \mathrm{C}_{\mathrm{org}}$ values of $\sim-26.5$ to $-25.6 \%$, followed by the falling limb just above the Oberer Stein. The $\delta^{13} \mathrm{C}_{\text {org }}$ record stabilizes at $\sim 28 \%$ in the upper part of the falciferum Zone (Fig. 6). The Toarcian pCIE reaches HI-corrected $\delta^{13} \mathrm{C}$ values of $+3.5 \%$, somewhat similar to $\delta^{13} \mathrm{C}_{\text {carb }}$ negative excursion recorded in Spanish and Portuguese brachiopods $+5.1 \%$ and $+5.8 \%$, respectively (Ullmann et al. 2020). The stabilization of the $\delta^{13} \mathrm{C}_{\text {org }}$ record at around $\sim 28 \%$ marks the return to normal marine $\delta^{13} \mathrm{C}_{\text {org }}$ conditions in the Aubach sediments (Fig. 6). The return to near-steady light $\delta^{13} \mathrm{C}$ values recorded in the $\delta^{13} \mathrm{C}$ reference curve span from the uppermost falciferum Zone to the lower part of the bifrons Zone (Ruebsam and Al-Husseini 2020). Thus, carbon-isotope values stayed relatively heavy for a substantial period of time after the culmination of the Toarcian pCIE. The elevated $\delta^{13} \mathrm{C}$ values may be a result of continued widespread organic matter burial, as high TOC values in levels post-dating the nCIE have been documented in several basins in Europe (this study, Röhl et al. 2001, Hermoso et al. 2013), Canada (Them et al. 2017a) and in Northern Siberia (Suan et al. 2011). The interval of high TOC post nCIE has been 
estimated to have lasted 600-1800 kyr in Northern Siberia (Suan et al. 2011).

\subsection{The magnitude of Toarcian negative CIE}

The exact magnitude of the nCIE is difficult to determine as differences in amplitude occur in different carbon reservoirs. This has made it challenging to estimate the amount of ${ }^{13} \mathrm{C}$-depleted carbon needed to create such a significant negative excursion as the Toarcian CIE (Kemp et al. 2005, Suan et al. 2015).

Our new $\delta^{13} \mathrm{C}_{\text {org }}$ profile for the Aubach section displays a nCIE magnitude of $-6.3 \%$. Other European sections record (uncorrected for $\mathrm{OM}$ source) similar amplitudes of $-6 \%$ to $-7 \%$ in the $\delta^{13} \mathrm{C}_{\text {org }}$ of bulk sedimentary organic matter (Jenkyns and Clayton 1997, Hesselbo et al. 2000, Röhl et al. 2001, Kemp et al. 2005, Hesselbo and Pienkowski 2011, Xu et al. 2018). Some researchers examined only the wood record in order to avoid bias introduced by OM source mixing, yet amplitudes may be as high as $-8 \%$ (Hesselbo et al. 2007, Pieńkowski et al. 2016, Hesselbo et al. 2000). However, degradation of fossil wood can alter $\delta^{13} \mathrm{C}$ depending on preservation stage (Ruebsam et al. 2020, Hesselbo et al. 2007). Changes in the hydrological cycle may also play a role and water availability has shown to affect the leaf gas-exchange and thereby cause up to $6 \%$ bias in $\delta^{13} \mathrm{C}$ of terrestrial plants during the PETM (Diefendorf et al. 2010). Increasing atmospheric $\mathrm{CO}_{2}\left(p \mathrm{CO}_{2}\right)$ may also affects terrestrial plant $\delta^{13} \mathrm{C}$, resulting in higher isotopic fractionation if $p \mathrm{CO}_{2}$ is more than $500 \mathrm{ppm}$ (Schubert and Jahren 2013). Ruebsam et al. (2020) estimated $p \mathrm{CO}_{2}$ during the nCIE to increase to as much as $1700 \mathrm{ppm}$. Magnitude variations of the nCIE between terrestrial and marine plants are seen in compound specific isotope ratios: $\delta^{13} \mathrm{C}$ of short-chain n-alkanes (marine indicators) give $\sim 2-3 \%$ whereas the $\delta^{13} \mathrm{C}$ of long-chain n-alkanes (terrestrial plants) is $\sim 4-5 \%$ in Yorkshire, UK (French et al. 2014).

Interestingly, the magnitude of the nCIE in the $\delta^{13} \mathrm{C}_{\text {carb }}$ record varies between individual sections. The magnitude of the nCIE is $\sim 4.5 \%$ in our record from Aubach, up to $6 \%$ in successions of the Paris Basin (Sancerre-Couy) and Mochras drillcore, Wales (Jenkyns et al. 2002), where as it is only $\sim 3.5 \%$ at Peniche (Hermoso et al. 2009b). Differences in magnitude of the $\delta^{13} \mathrm{C}_{\text {carb }}$ may be attributed to the sensitivity to diagenesis or to local effects. The latter can be significant especially in deposits of shallow marine epicontinental seas, such as the Laurasian Seaway, in which the dissolved inorganic carbon $\delta^{13} \mathrm{C}$ is more sensitive to changes in the water column compared to pelagic sediments of the deep ocean (Immenhauser et al. 2008). The carbonate carbon-isotope ratios from the Unterer Stein limestone bed are very low, and the $\delta^{18} \mathrm{O}_{\text {carb }}$ signals are highly variable, both suggesting that these samples are diagenetically altered. These samples have therefore been excluded from the interpretation (Fig. S1).

The drivers for the Toarcian nCIE are the subject of controversial discussion. Several causes have been proposed over the years. One of the first, suggested by Küspert (1982), was the recycling of isotopically light carbon in the restricted water column. Volcanic $\mathrm{CO}_{2}$ sourced from the Karoo Large Igneous Province may have injected ${ }^{13} \mathrm{C}$-depleted into the atmosphere causing the nCIE (Hesselbo et al. 2007, Hermoso et al. 2009b). However Gröcke et al. (2009) reject magmatism as the cause for the $\mathrm{nCIE}$ as $\delta^{13} \mathrm{C}$ values from volatile matter and vitrinite reflectance from two coal transects associated with dykes from the Karoo Basin, $\mathrm{S}$ Africa show no significant change in $\delta^{13} \mathrm{C}$ (which would be expected by thermogenic $\mathrm{CH}_{4}$ generation). Data indicate that the dyke intrusions occurred when the coal still had a high moisture content prohibiting $\mathrm{CH}_{4}$ generation (Gröcke et al. 2009). Alternatively, an injection of ${ }^{13} \mathrm{C}$-depleted carbon from methane release from various reservoirs (gas hydrates, wetlands, permafrost or from fossil wood degradation) may be responsible for the Toarcian nCIE, possibly secondarily paced by astronomical-forcing (Hesselbo et al. 2000, Them et al. 2017a, Ruebsam et al. 2019, Kemp et al. 2005, Pieńkowski et al. 2016).

\subsubsection{HI-correction of $\delta^{13} C_{\text {org }}$}

Schouten et al. (2000) established that the difference in magnitude of the nCIE between carbon reservoirs was not a result of changes in a photosynthetic fractionation factor caused by increasing $p \mathrm{CO}_{2}$ during the T-OAE, because marine molecular-compound specific $\delta^{13} \mathrm{C}$ of the $\mathrm{OM}$ displayed similar amplitudes as $\delta^{13} \mathrm{C}_{\mathrm{carb}}$. However, fluctuations in OM source affect $\delta^{13} \mathrm{C}_{\text {org }}$ (Van de Schootbrugge et al. 2013) and may account for the difference between marine $\delta^{13} \mathrm{C}_{\mathrm{org}}$ and $\delta^{13} \mathrm{C}_{\text {carb }}$; this can be corrected for by applying the HI-correction as in Lenniger et al. (2014) and Suan et al. (2015; see results).

The matrix effect of high carbonate concentrations can lower the HI value and thereby affect the accuracy 
of the HI-correction (Suan et al. 2015). Yet this is not the case in the Aubach section as strong HI similarities occur in coeval sediments of other sections in the vicinity of the Wutach area (e.g., Denkingen and Dotternhausen, SW Germany; Suan et al. 2015). By applying this $\mathrm{HI}$-correction on $\delta^{13} \mathrm{C}_{\mathrm{org}}$, the amplitude of the nCIE is reduced to $3.3-3.5 \%$ in Aubach (Fig. 2). Thus, the excursion magnitude becomes comparable to that observed in $\delta^{13} \mathrm{C}_{\text {carb }}(4.5 \%)$, the brachiopod record of Spain (4.2\%o; Ullmann et al. 2020) and marine and lacustrine compound specific isotopes (2-4\%); (French et al. 2014, Schouten et al. 2000, Xu et al. 2017). Three other German sections, Denkingen and Dotternhausen (Suan et al. 2015) and Rietheim (Montero-Serrano et al. 2015) report nCIE of 3-4 \%o after HI-correction, and is in concert with the $\delta^{13} \mathrm{C}_{\text {carb }}$ fluctuation in all the sections. Thus, correction for changing in $\mathrm{OM}$ seems of great importance in understanding the severe environmental perturbation. For comparison with other successions, we will discuss the uncorrected $\delta^{13} \mathrm{C}_{\text {org }}$ curve, as the uncorrected curve relates directly to local environmental changes such as redox.

\subsection{Environmental changes in the Early Toarcian in Aubach}

A selection of redox sensitive elements (V/Al and DOP-T) were used to determine the redox conditions in the sediments of the Aubach section (Fig. 5). Vanadium is fixed in sedimentary organic matter in anoxic waters, when $\mathrm{V}(\mathrm{V})$ is reduced to $\mathrm{V}(\mathrm{IV})$, which is adsorbed onto settling organic compounds (Breit and Wanty 1991). V is remobilized back into the water column when OM is oxidized for dysoxic waters above and below modern anoxic zones in the oceans (Wang et al. 2017). DOP-T ( $\mathrm{S} /$ total $\mathrm{Fe}$ ) is a simple, good indicator for redox conditions during deposition based on the degree of pyritization (Algeo and Maynard 2008, Berner et al. 2013). The formation of pyrite is limited by the abundance of reactive $\mathrm{Fe}$ and $\mathrm{H}_{2} \mathrm{~S}$ in local environment. Frambodial pyrite precipitating in the euxinic water column/pore water forms via a metastable phase, Fe-sulfide (FeS), and then transforms into pyrite $\left(\mathrm{FeS}_{2}\right)$ if the sulfur species are avaliable. Sulphate-reducing bacteria control the production of sulfur and sufides avaliable for pyrite formation (e. g., Berner et al. 2013).

In general suboxic to dysoxic conditions characterized the semicelatum Zone as indicated by DOP-T of 0.25-0.5. Simultaneously, low V/Al ratios combined with low \%TOC, Kerogen Type III OM and the marly bioturbated lithology support the more oxygenated conditions in the Swabo-Franconian Basin prior to the nCIE. Most likely the V was remobilized postdepositionally during $\mathrm{OM}$ oxidation explaining the relationship between low TOC and low V concentrations (Fig. 5). The discrete black shale horizons within the semicelatum Zone coincide with high $\mathrm{V} / \mathrm{Al}$ ratios and DOP-T $>0.50$, supporting the interpretation of short intervals of anoxia (Röhl et al. 2001). The HIcorrection removes the light $\delta^{13} \mathrm{C}_{\text {org }}$ values occurring in the shales, suggesting a strong lithological control on the organic matter (kerogen type). These short-term intervals of oxygen deficiency are also recognized in some basins: Yorkshire, UK (McArthur et al. 2008, Thibault et al. 2018) and Dotternhausen (Röhl et al. 2001), which may suggest a connection between these basins or concurrent local outbreaks of anoxia.

\subsubsection{Expression of the T-OAE in the Aubach section}

We adopt the definition of an OAE by the positive $\delta^{13} \mathrm{C}$ perturbation, setting the beginning of the OAE where $\delta^{13} \mathrm{C}$ values start to increase and the end at the climax of the rising $\delta^{13} \mathrm{C}$ limb of the positive excursion (Jenkyns 2010). This definition sets the end of the T-OAE in the lower falciferum Zone near the Oberer Stein (Fig. 6). Long-term V/Al enrichment and DOP-T $>0.5$ indicates that anoxia-euxinia initiated in the uppermost semicelatum Zone, synchronous with the first negative step in $\delta^{13} \mathrm{C}_{\text {org }}$ (Fig. 5). Thus, longlasting anoxia and enhanced OM burial in the Aubach section is delayed compared to the beginning of the T-OAE, and may be directly related to the environmental changes linked to the nCIE. Global warming in Early Toarcian led to enhanced continental weathering, especially during the CIE (Them et al. 2017b, Cohen et al. 2007, Percival et al. 2016, Xu et al. 2018). The increased weathering boosted the supply of phosphorous and other nutrients to the ocean, which enhanced the primary productivity in the photic zone (Röhl et al. 2001). Oxidation of this OM-lean to oxygen deficiency deeper in the water column, and even photic zone euxinia (Ruebsam et al. 2018).

Vanadium usually accumulates in the sediment fixed in organic compounds. This may explain the low V/Al ratios in the two organic matter-lean limestone beds in the anoxic-euxinic interval (Fig. 5). Aryl isoprenoid and isorenieratane biomarkers occur in the Unterer Stein and Oberer Stein in the nearby Dotternhausen 

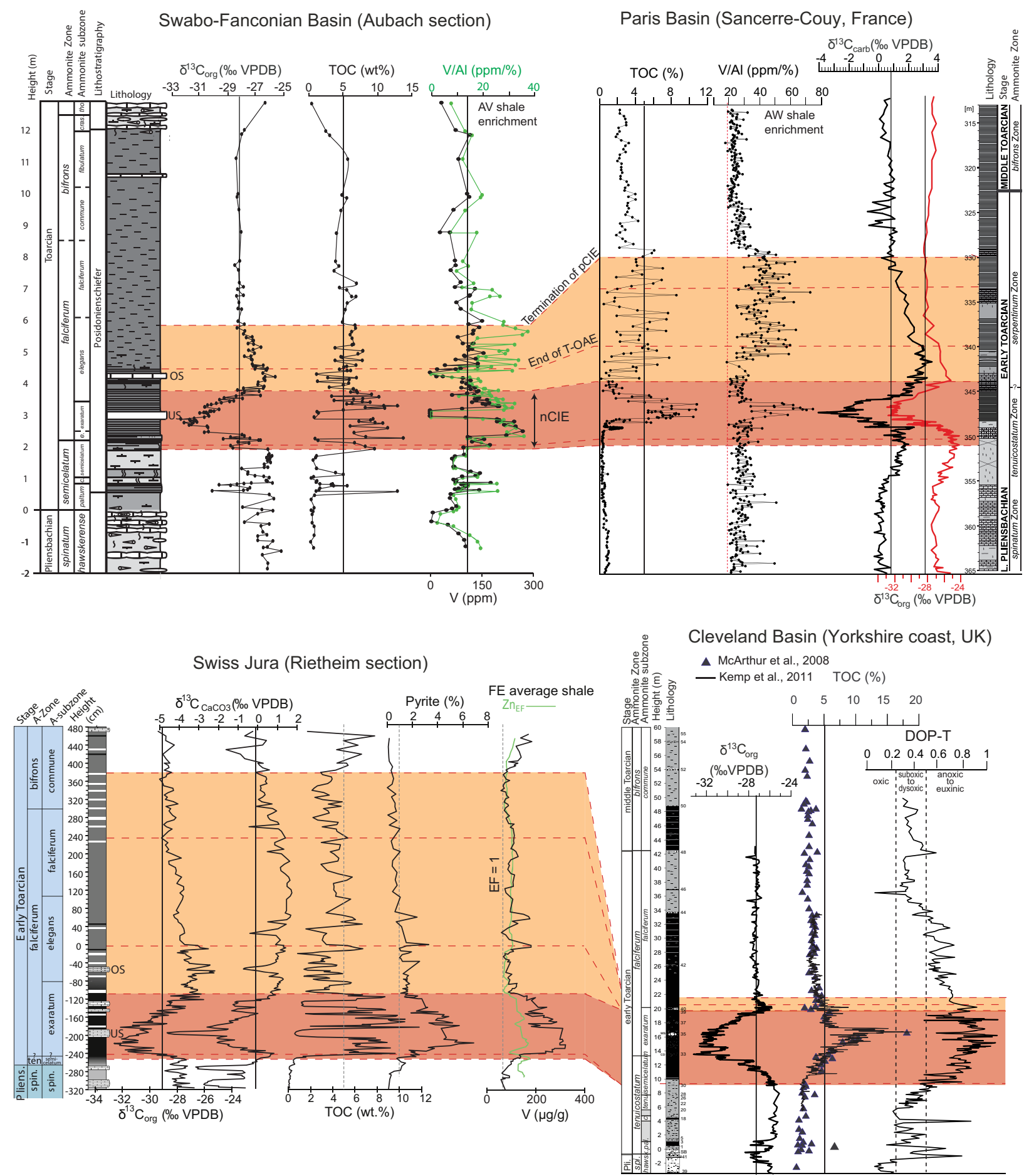

Fig. 7. Correlation of the Aubach section (Swabo-Franconian Basin), Sancerre-Couy core (Paris Basin; Hermoso et al. 2013) and Yorkshire section (Cleveland Basin; Littler et al. 2010, Thibault et al. 2018) based on the correlation in Ruebsam and Al-Husseini (2020). The correlation to the Rietheim section (Swiss Jura; Montero-Sancarro et al. 2015) is based on their definition of the nCIE and the return to steady light $\delta^{13} \mathrm{C}_{\mathrm{org}}$. The coherence between termination of the Toarcian pCIE and end of TOC $>5 \%$ and anoxic-euxinic conditions in the upper falciferum/serpentinum Zone occurs in the Aubach section and in the Sancerre-Couy core. However, in the Yorkshire section DOP-T of $0.5-1$ continues after $\delta^{13} C_{\text {org }}$ has stabilized, and in the nearby Rietheim section V-enrichment and TOC $>5 \%$ only occurs during the nCIE. 
section, indicating that the limestone beds formed during photic zone anoxia-euxinia (Schouten et al. 2000, Schwark and Frimmel 2004). V/Al enrichment and DOP-T of $0.5-1$ suggest that anoxic-euxinic conditions prevailed until the late falciferum Zone in the Aubach section, accompanied by TOC content $>5 \%$ (Fig. 5). Thus, anoxia and deposition of organicrich shales continued after the defined end of the OAE in the lower falciferum Zone (Fig. 6). The continuation of anoxia after the maximum of the positive excursion has also been observed in nearby Dotternhausen section and in Sancerre Couy, Paris Basin (Röhl et al. 2001, Hermoso et al. 2013). Thallium isotopes from Dotternhausen remain high throughout the Early Toarcian suggesting that anoxia continued after enhanced organic matter burial ended (Them et al. 2018).

Interestingly, the end of anoxic-euxinic conditions (with abatement of V/Al enrichment and elevated DOP-T $0.5-1$ ) and the termination of TOC $>5 \%$ occur synchronously with the return to steady light ${ }^{13} \mathrm{C}_{\text {org }}$ values in the Aubach section (Fig. 5 and 7). This also appears to be the case in the southern Paris Basin (Sancerry-Couy Core) where [V/Al] and TOC content decrease just after the return to steady light $\delta^{13} \mathrm{C}$ values (Fig. 7). The \%TOC stabilizes synchronously with $\delta^{13} \mathrm{C}_{\text {org }}$ in Yorkshire as well, suggesting a coupling between the proxies. However, a coherence between redox sensitive proxies (DOP-T) and $\delta^{13} \mathrm{C}$ is not present (Fig. 7). V/Al ratios and DOP-Tare not documented for the nearby Dotternhausen section, so a direct comparison is not possible. However, redox sensitive biomarkers $(\mathrm{Pr} / \mathrm{Ph}$ and Aryl isoprenoid ratios) decrease where $\delta^{13} \mathrm{C}_{\text {org }}$ return to steady light values in lower bifrons Zone (Fig. 3 in Schwark and Frimmel 2004), suggesting the same mirroring of $\delta^{13} \mathrm{C}$ and redox sensitive proxies here, whereas TOC of more than $5 \%$ occur throughout the bifrons Zone (Röhl et al. 2001).

In contrast, the Iberian Range, Spain (Reolid 2014), Morocco, N-Africa (Krencker et al. 2020), and Peniche section, Lusitanian Basin (Fantasia et al. 2019, Hermoso et al. 2009b) were more oxygenated, and longterm anoxia never developed during the T-OAE. The transect between anoxic and oxic locations is well illustrated across the southern epi-continental margin (S Germanic and Swiss locations) displaying the transition from the anoxic Swabo-Franconian Basin (this study, Röhl et al. 2001, Dickson et al. 2017) to the dysoxic-anoxic northern shelf (Fig. 7) (Montero-Serrano et al. 2015) to the oxic Lombardian Basin on the continental margin (Fantasia et al. 2018). The T-OAE as an environmental perturbation is thus not necessa- rily synchronous in different basins, yet the nCIE of the T-OAE still serves well as a detailed stratigraphic correlation (Ruebsam and Al-Husseini 2020). The non-identical redox conditions during and after the T-OAE in European sections illustrate well that the drivers of anoxia was, at least partly, regionally influenced. Redox sensitive proxies (V/Al and DOP-T) indicate that anoxic-euxinic conditions prevailed in the inner-epicontinental Sea until the upper falciferum Zone, concurrent with the return to stable light $\delta^{13} \mathrm{C}$ values.

\subsection{Decoupling between $\delta^{13} \mathrm{C}$ and organic matter burial}

Deposition of black shale (TOC $>5 \%$ ) in the Aubach section preceded the stratigraphic extent of the positive limb of $\delta^{13} \mathrm{C}$ excursion (Fig. 2) and by definition the end of the T-OAE (cf. Jenkyns 2010; Fig. 6). This suggests that local scale black shale formation did not solely drive $\delta^{13} \mathrm{C}_{\text {org. }}$. If $\delta^{13} \mathrm{C}_{\text {org }}$ were exclusively governed by local processes, primary productivity and organic carbon burial (e. g., Scholle and Arthur 1980), the TOC content and $\delta^{13} \mathrm{C}_{\text {org }}$ would be expected to stratigraphically mirror each other, if we assume that type of organic matter and growth rate were constant. An increase in these local processes will thereby lead to an increase in $\delta^{13} \mathrm{C}$ of the local dissolved inorganic carbon (DIC) and finally in the $\delta^{13} \mathrm{C}_{\mathrm{org}}$ and $\delta^{13} \mathrm{C}_{\text {carb }}$ (Scholle and Arthur 1980). The fact that black shale deposition ( $\%$ TOC $>5 \%$ ) precedes the rising $\delta^{13} \mathrm{C}_{\text {org }}$ values document a partial decoupling of the pCIE and organic carbon burial in the Aubach section (Fig. 2). This suggests that the local pCIE were only partly influenced by regional seawater circumstances, and thus other factors must have impacted the local $\delta^{13} \mathrm{C}_{\text {DIC }}$. Changes in atmospheric $\mathrm{CO}_{2}\left(p \mathrm{CO}_{2}\right)$ levels would affect the local $\delta^{13} \mathrm{C}_{\text {DIC }}$ as atmosphere and the upper mixed layer are in equilibrium (Revelle and Suess 1957). A global decline in $p \mathrm{CO}_{2}$ is expected after the nCIE, as a result of the widespread organic carbon burial (Ruebsam et al. 2018) and intensified chemical weathering indicated by elevated Osmium isotope values (Them et al. 2017b). The local pCIE may be a result of 1) a global decline in $p \mathrm{CO}_{2}$ after the nCIE, and 2) local changes in bioproductivity and organic carbon burial. However, this call for further investigation.

We observe a stratigraphic relationship between termination of black shale formation (TOC $>5 \%$ ) and the end of the Toarcian pCIE in the Aubach, 
Sancerre Couy and Yorkshire locations (Fig. 7). Previous studies have also shown that black shale formation continued after the maximum of the Toarcian pCIE in basins worldwide (Them et al. 2017a, Röhl et al. 2001, Hermoso et al. 2013, Suan et al. 2011) by comparison to what is expected from theoretical models (Ullmann et al. 2020) as the maximum of the Toarcian pCIE is commonly used to define the termination of the T-OAE. This mismatch between proxies, warning us that prolonged anoxia locally occur long after the peak in the carbon cycle perturbation call for a revision of the definition of the T-OAE. Furthermore, the T-OAE may serve as an analogue for the anthropogenic carbon pertubation. This suggests that the environment recovery will be substantially delayed in many places, after we have the release of ${ }^{12} \mathrm{C}$ to the atmosphere under control.

\section{Conclusions}

This study examines carbon isotope, redox element and Rock Eval records across the Early Toarcian interval in the Aubach section, SW Germany, which are compared to published data from other European sections. We find that the negative carbon isotope event (nCIE) record in the Aubach section is reduced from $\delta^{13} \mathrm{C}_{\text {org }} 6.3 \%$ to $3.5-3.3 \%$ after applying a $\mathrm{HI}$ correction which is comparable to the carbonate $\delta^{13} \mathrm{C}$ record $(4.5 \%)$. This shows that it may be worth accounting for variable $\mathrm{OM}$ sources to understand the magnitude of the nCIE better.

The onset of long-term anoxia indicated by $\mathrm{V} / \mathrm{Al}$ enrichment and DOP-T of $0.5-1$ and TOC of more than $5 \%$ initiate in the upper semicelatum Zone. This occurs concurrently with the first negative shift in $\delta^{13} \mathrm{C}_{\mathrm{org}}$. The redox element record indicates that anoxic-euxinic conditions prevailed until the late falciferum Zone, concurrent with the return to stable $\delta^{13} \mathrm{C}_{\text {org }}$ values at $\sim-28 \%$. We define the termination of the Toarcian positive CIE based on the return to steady light $\delta^{13} \mathrm{C}_{\text {org }}$ values in the upper falciferum Zone, which we believe marks the return to normal marine conditions in the Aubach section. This coherence between return to stable $\delta^{13} \mathrm{C}_{\text {org }}$ values and the end of $\mathrm{V} / \mathrm{Al}$ enrichment and TOC $>5 \%$ also occurs in the Sancerre-Couy (southern Paris Basin). In Yorkshire (Cleveland Ba$\sin$ ), there is only synchronism between the $\delta^{13} \mathrm{C}_{\text {org }}$ and $\%$ TOC trends but not in redox conditions. The return to normal marine conditions seems to be synchronous in the some European basins but not all, highlighting the need for further investigation.

Acknowledgements. We acknowledge Bo Petersen (Copenhagen) and Carsten Guvad (GEUS) for analytical assistance and Stephen Hesselbo (Exeter) for discussion. The Danish Council for Independent Research-Natural Sciences (project DFF-7014-00142 to CK) is thanked for contributions to financing this project.

\section{References}

Algeo, T. J., Maynard, J. B., 2004. Trace-element behavior and redox facies in core shales of Upper Pennsylvanian Kansastype cyclothems. Chemical Geology 206, 289-318.

Algeo, T. J., Maynard, J. B., 2008. Trace-metal covariation as a guide to water-mass conditions in ancient anoxic marine environments. Geosphere 4, 872-887.

Al-Suwaidi, A., Angelozzi, G., Baudin, F., Damborenea, S., Hesselbo, S., Jenkyns, H., Manceñido, M., Riccardi, A., 2010. First record of the Early Toarcian oceanic anoxic event from the Southern Hemisphere, Neuquén Basin, Argentina. Journal of the Geological Society 167, 633-636.

Bailey, T., Rosenthal, Y., McArthur, J., Van De Schootbrugge, B., Thirlwall, M., 2003. Paleoceanographic changes of the Late Pliensbachian-Early Toarcian interval: a possible link to the genesis of an Oceanic Anoxic Event. Earth and Planetary Science Letters 212, 307-320.

Berner, Z. A., Puchelt, H., Noeltner, T., Kramar, U., 2013. Pyrite geochemistry in the Toarcian Posidonia Shale of south-west Germany: Evidence for contrasting traceelement patterns of diagenetic and syngenetic pyrites. Sedimentology 60, 548-573.

Bjerrum, C. J., Surlyk, F., Callomon, J.H., Slingerland, R. L., 2001. Numerical paleoceanographic study of the Early Jurassic transcontinental Laurasian Seaway. Paleoceanography 16, 390-404.

Breit, G. N., Wanty, R. B., 1991. Vanadium accumulation in carbonaceous rocks: a review of geochemical controls during deposition and diagenesis. Chemical Geology 91, 83-97.

Cohen, A.S., Coe, A.L., Kemp, D.B., 2007. The late Palaeocene-Early Eocene and Toarcian (Early Jurassic) carbon isotope excursions: a comparison of their time scales, associated environmental changes, causes and consequences. Journal of the Geological Society 164, 1093-1108.

Demoulin, A., Launoy, T., Zippelt, K., 1998. Recent crustal movements in the southern Black Forest (western Germany). Geologische Rundschau 87, 43-52.

Dickson, A. J., Gill, B. C., Ruhl, M., Jenkyns, H. C., Porcelli, D., Idiz, E., Lyons, T. W., van den Boorn, S. H., 2017. Molybdenum-isotope chemostratigraphy and paleoceanography of the Toarcian Oceanic Anoxic Event (Early Jurassic). Paleoceanography 32, 813-829. 
Diefendorf, A. F., Mueller, K.E., Wing, S. L., Koch, P. L., Freeman, K. H., 2010. Global patterns in leaf ${ }^{13} \mathrm{C}$ discrimination and implications for studies of past and future climate. Proceedings of the National Academy of Sciences 107, 5738-5743.

Fantasia, A., Adatte, T., Spangenberg, J. E., Font, E., Duarte, L. V., Föllmi, K. B., 2019. Global versus local processes during the Pliensbachian-Toarcian transition at the Peniche GSSP, Portugal: A multi-proxy record. EarthScience Reviews 198, 102932.

Fantasia, A., Föllmi, K. B., Adatte, T., Bernárdez, E., Spangenberg, J. E., Mattioli, E., 2018a. The Toarcian oceanic anoxic event in southwestern Gondwana: An example from the Andean basin, northern Chile. Journal of the Geological Society 175, 883-902.

Fantasia, A., Föllmi, K. B., Adatte, T., Spangenberg, J.E., Montero-Serrano, J.-C., 2018b. The Early Toarcian oceanic anoxic event: Paleoenvironmental and paleoclimatic change across the Alpine Tethys (Switzerland). Global and Planetary Change 162, 53-68.

French, K., Sepúlveda, J., Trabucho-Alexandre, J., Gröcke, D., Summons, R., 2014. Organic geochemistry of the early Toarcian oceanic anoxic event in Hawsker Bottoms, Yorkshire, England. Earth and Planetary Science Letters 390, 116-127.

Frimmel, A., Oschmann, W., Schwark, L., 2004. Chemostratigraphy of the Posidonia Black Shale, SW Germany: I. Influence of sea-level variation on organic facies evolution. Chemical Geology 206, 199-230.

Gröcke, D., Hori, R., Trabucho-Alexandre, J., Kemp, D., Schwark, L., 2011. An open ocean record of the Toarcian oceanic anoxic event. Solid Earth 2, 245-257.

Gröcke, D. R., Hesselbo, S. P., Jenkyns, H. C., 1999. Carbonisotope composition of Lower Cretaceous fossil wood: Ocean-atmosphere chemistry and relation to sea-level change. Geology 27, 155-158.

Gröcke, D. R., Rimmer, S. M., Yoksoulian, L. E., Cairncross, B., Tsikos, H., van Hunen, J., 2009. No evidence for thermogenic methane release in coal from the KarooFerrar large igneous province. Earth and Planetary Science Letters 277, 204-212.

Hermoso, M., Le Callonnec, L., Minoletti, F., Renard, M., Hesselbo, S. P., 2009a. Expression of the Early Toarcian negative carbon-isotope excursion in separated carbonate microfractions (Jurassic, Paris Basin). Earth and Planetary Science Letters 277, 194-203.

Hermoso, M., Minoletti, F., Le Callonnec, L., Jenkyns, H. C., Hesselbo, S. P., Rickaby, R. E. M., Renard, M., de Rafelis, M., Emmanuel, L., 2009b. Global and local forcing of Early Toarcian seawater chemistry: A comparative study of different paleoceanographic settings (Paris and Lusitanian basins). Paleoceanography 24, PA 4208.

Hermoso, M., Minoletti, F., Pellenard, P., 2013. Black shale deposition during Toarcian super-greenhouse driven by sea level. Climate of the Past 9, 2703-2712.

Hermoso, M., Minoletti, F., Rickaby, R. E., Hesselbo, S. P., Baudin, F., Jenkyns, H. C., 2012. Dynamics of a stepped carbon-isotope excursion: Ultra high-resolution study of
Early Toarcian environmental change. Earth and Planetary Science Letters 319, 45-54.

Hesselbo, S. P., Gröcke, D. R., Jenkyns, H. C., Bjerrum, C. J., Farrimond, P., Bell, H. S. M., Green, O. R., 2000. Massive dissociation of gas hydrate during a Jurassic oceanic anoxic event. Nature 406, 392-395.

Hesselbo, S. P., Jenkyns, H. C., Duarte, L. V., Oliveira, L. C., 2007. Carbon-isotope record of the Early Jurassic (Toarcian) Oceanic Anoxic Event from fossil wood and marine carbonate (Lusitanian Basin, Portugal). Earth and Planetary Science Letters 253, 455-470.

Hesselbo, S. P., Pienkowski, G., 2011. Stepwise atmospheric carbon-isotope excursion during the Toarcian oceanic anoxic event (Early Jurassic, Polish Basin). Earth and Planetary Science Letters 301, 365-372.

Hunt, J. M., 1996. Petroleum Geochemistry and Geology, New York, W. H. Freeman and Company.

Immenhauser, A., Holmden, C., Patterson, W. P., 2008. Interpreting the carbon-isotope record of ancient shallow epeiric seas: lessons from the recent: lessons from the recent, Dynamics of Epeiric Seas. Geological Association of Canada Special Publication 48, 135-174.

Jenkyns, H., 1988. The early Toarcian (Jurassic) anoxic event-stratigraphic, sedimentary, and geochemical evidence. American Journal of Science 288, 101-151.

Jenkyns, H.C., 2010. Geochemistry of oceanic anoxic events. Geochemistry Geophysics Geosystems 11 (3), Q03004.

Jenkyns, H.C., Clayton, C. J., 1997. Lower Jurassic epicontinental carbonates and mudstones from England and Wales: chemostratigraphic signals and the early Toarcian anoxic event. Sedimentology 44, 687-706.

Jenkyns, H. C., Jones, C. E., Gröcke, D. R., Hesselbo, S. P., Parkinson, D. N., 2002. Chemostratigraphy of the Jurassic System: applications, limitations and implications for palaeoceanography. Journal of the Geological Society 159, 351-378.

Kemp, D. B., Baranyi, V., Izumi, K., Burgess, R. D., 2019. Organic matter variations and links to climate across the early Toarcian oceanic anoxic event (T-OAE) in Toyora area, southwest Japan. Palaeogeography, Palaeoclimatology, Palaeoecology 530, 90-102.

Kemp, D. B., Coe, A. L., Cohen, A. S., Schwark, L., 2005. Astronomical pacing of methane release in the Early Jurassic period. Nature 437, 396-399.

Korte, C., Hesselbo, S. P., Ullmann, C. V., Dietl, G., Ruhl, M., Schweigert, G., Thibault, N., 2015. Jurassic climate mode governed by ocean gateway. Nature Communication 6, 10015.

Krencker, F.-N., Fantasia, A., Danisch, J., Martindale, R., Kabiri, L., El Ouali, M., Bodin, S., 2020. Two-phased collapse of the shallow-water carbonate factory during the late Pliensbachian-Toarcian driven by changing climate and enhanced continental weathering in the Northwestern Gondwana Margin. Earth-Science Reviews, 103254.

Küspert, W., 1982. Cyclic and Event Stratification. Springer, 482-501. 
Lenniger, M., Nøhr-Hansen, H., Hills, L. V., Bjerrum, C. J., 2014. Arctic black shale formation during Cretaceous oceanic anoxic event 2. Geology 42, 799-802.

Littler, K., Hesselbo, S. P., Jenkyns, H. C., 2010. A carbonisotope perturbation at the Pliensbachian-Toarcian boundary: evidence from the Lias Group, NE England. Geological Magazine 147, 181-192.

McArthur, J. M., Algeo, T. J., van de Schootbrugge, B., Li, Q., Howarth, R. J., 2008. Basinal restriction, black shales, Re-Os dating, and the Early Toarcian (Jurassic) oceanic anoxic event. Paleoceanography 23, PA4217.

Moldowan, J. M., Sundararaman, P., Schoell, M., 1986. Sensitivity of biomarker properties to depositional environment and/or source input in the Lower Toarcian of SW-Germany. Organic Geochemistry 10, 915-926.

Montero-Serrano, J.-C., Föllmi, K. B., Adatte, T., Spangenberg, J. E., Tribovillard, N., Fantasia, A., Suan, G., 2015. Continental weathering and redox conditions during the early Toarcian Oceanic Anoxic Event in the northwestern Tethys: Insight from the Posidonia Shale section in the Swiss Jura Mountains. Palaeogeography, Palaeoclimatology, Palaeoecology 429, 83-99.

Percival, L. M., Cohen, A., Davies, M., Dickson, A., Hesselbo, S., Jenkyns, H., Leng, M., Mather, T., Storm, M., $\mathrm{Xu}, \mathrm{W} ., 2016$. Osmium isotope evidence for two pulses of increased continental weathering linked to Early Jurassic volcanism and climate change. Geology 44, 759-762.

Pieńkowski, G., Hodbod, M., Ullmann, C. V., 2016. Fungal decomposition of terrestrial organic matter accelerated Early Jurassic climate warming. Scientific Reports 6, 1-11.

Reolid, M., 2014. Pyritized radiolarians and siliceous sponges from oxygen-restricted deposits (Lower Toarcian, Jurassic). Facies 60, 789-799.

Revelle, R., Suess, H. E., 1957. Carbon dioxide exchange between atmosphere and ocean and the question of an increase of atmospheric $\mathrm{CO}_{2}$ during the past decades. Tellus 9, 18-27.

Riegraf, W., Werner, G., Lörcher, F., 1984. Der Posidonienschiefer - Biostratigraphy, Fauna und Fazies des südwestdeutschen Untertoarciums (Lias $\varepsilon$ ). Enke, Stuttgart, $195 \mathrm{p}$.

Ruebsam, W., Al-Husseini, M., 2020. Calibrating the Early Toarcian (Early Jurassic) with stratigraphic black holes (SBH). Gondwana Research 82, 317-336.

Ruebsam, W., Mayer, B., Schwark, L., 2019. Cryosphere carbon dynamics control early Toarcian global warming and sea level evolution. Global and Planetary Change 172, 440-453.

Ruebsam, W., Müller, T., Kovács, J., Pálfy, J., Schwark, L., 2018. Environmental response to the early Toarcian carbon cycle and climate perturbations in the northeastern part of the West Tethys shelf. Gondwana Research 59, 144-158.

Ruebsam, W., Reolid, M., Schwark, L., 2020. $\delta^{13} \mathrm{C}$ of terrestrial vegetation records Toarcian $\mathrm{CO}_{2}$ and climate gradients. Scientific Reports 10, 1-8.

Röhl, H.-J., Schmid-Röhl, A., 2005. Lower Toarcian (Upper Liassic) black shales of the Central European epiconti- nental basin: a sequence stratigraphic case study from the SW German Posidonia Shale. SEPM (Society for Sedimentary Geology) Special Publication 82, 165-189.

Röhl, H.-J., Schmid-Röhl, A., Oschmann, W., Frimmel, A., Schwark, L., 2001. Erratum to "The Posidonia Shale (Lower Toarcian) of SW-Germany: an oxygen-depleted ecosystem controlled by sea level and palaeoclimate" [Palaeogeogr., Palaeoclimatol., Palaeocol. 165 (2001) 27-52]. Palaeogeography, Palaeoclimatology, Palaeoecology 169, 273-299.

Scholle, P. A., Arthur, M. A., 1980. Carbon isotope fluctuations in Cretaceous pelagic limestones: potential stratigraphic and petroleum exploration tool. AAPG Bulletin 64, 67-87.

Schouten, S., van Kaam-Peters, H. M. E., Rijpstra, W. I. C., Schoell, M., Damste, J. S. S., 2000. Effects of an oceanic anoxic event on the stable carbon isotopic composition of early Toarcian carbon. American Journal of Science 300, $1-22$.

Schubert, B.A., Jahren, A.H., 2013. Reconciliation of marine and terrestrial carbon isotope excursions based on changing atmospheric $\mathrm{CO}_{2}$ levels. Nature Communications 4, 1-6.

Schwark, L., Frimmel, A., 2004. Chemostratigraphy of the Posidonia Black Shale, SW-Germany: II. Assessment of extent and persistence of photic-zone anoxia using aryl isoprenoid distributions. Chemical Geology 206, 231-248.

Suan, G., Nikitenko, B. L., Rogov, M. A., Baudin, F., Spangenberg, J. E., Knyazev, V. G., Glinskikh, L. A., Goryacheva, A. A., Adatte, T., Riding, J. B., 2011. Polar record of Early Jurassic massive carbon injection. Earth and Planetary Science Letters 312, 102-113.

Suan, G., Pittet, B., Bour, I., Mattioli, E., Duarte, L. V., Mailliot, S., 2008. Duration of the Early Toarcian carbon isotope excursion deduced from spectral analysis: consequence for its possible causes. Earth and Planetary Science Letters 267, 666-679.

Suan, G., Van De Schootbrugge, B., Adatte, T., Fiebig, J., Oschmann, W., 2015. Calibrating the magnitude of the Toarcian carbon cycle perturbation. Paleoceanography 30, 495-509.

Them, T., Gill, B., Caruthers, A., Gröcke, D., Tulsky, E., Martindale, R., Poulton, T., Smith, P., 2017a. Highresolution carbon isotope records of the Toarcian Oceanic Anoxic Event (Early Jurassic) from North America and implications for the global drivers of the Toarcian carbon cycle. Earth and Planetary Science Letters 459, 118-126. Them, T. R., Gill, B. C., Caruthers, A.H., Gerhardt, A. M., Gröcke, D. R., Lyons, T. W., Marroquín, S. M., Nielsen, S. G., Alexandre, J. P. T., Owens, J. D., 2018. Thallium isotopes reveal protracted anoxia during the Toarcian (Early Jurassic) associated with volcanism, carbon burial, and mass extinction. Proceedings of the National Academy of Sciences 115, 6596-6601.

Them, T. R., Gill, B. C., Selby, D., Gröcke, D. R., Friedman, R. M., Owens, J. D., 2017b. Evidence for rapid weathering response to climatic warming during the Toarcian Oceanic Anoxic Event. Scientific Reports 7, 1-10. 
Thibault, N., Ruhl, M., Ullmann, C. V., Korte, C., Kemp, D. B., Gröcke, D. R., Hesselbo, S. P., 2018. The wider context of the Lower Jurassic Toarcian oceanic anoxic event in Yorkshire coastal outcrops, UK. Proceedings of the Geologists' Association 129, 372-391.

Ullmann, C., Boyle, R., Duarte, L., Hesselbo, S., Kasemann, S., Klein, T., Lenton, T., Piazza, V., Aberhan, M., 2020. Warm afterglow from the toarcian oceanic Anoxic event drives the success of deep-adapted brachiopods. Scientific Reports 10, 1-11.

Ullmann, C. V., Campbell, H. J., Frei, R., Hesselbo, S. P., Pogge von Strandmann, P. A., Korte, C., 2013. Partial diagenetic overprint of Late Jurassic belemnites from New Zealand: Implications for the preservation potential of $\delta^{7} \mathrm{Li}$ values in calcite fossils. Geochimica et Cosmochimica Acta 120, 80-96.

Van de Schootbrugge, B., Bachan, A., Suan, G., Richoz, S., Payne, J. L., 2013. Microbes, mud and methane: cause and consequence of recurrent Early Jurassic anoxia following the end-Triassic mass extinction. Palaeontology 56, 685-709.

Wang, X., Zhang, S., Wang, H., Bjerrum, C. J., Hammarlund, E. U., Haxen, E. R., Su, J., Wang, Y., Canfield, D. E., 2017. Oxygen, climate and the chemical evolution of a 1400 million year old tropical marine setting. American Journal of Science 317, 861-900.
Wedepohl, K., 1971. Environmental influences on the chemical composition of shales and clays. Physics and Chemistry of the Earth 8, 307-333.

Wignall, P. B., Newton, R. J., Little, C. T., 2005. The timing of paleoenvironmental change and cause-and-effect relationships during the Early Jurassic mass extinction in Europe. American Journal of Science 305, 1014-1032.

Xu, W., Ruhl, M., Jenkyns, H. C., Hesselbo, S. P., Riding, J. B., Selby, D., Naafs, B. D. A., Weijers, J. W., Pancost, R. D., Tegelaar, E. W., 2017. Carbon sequestration in an expanded lake system during the Toarcian oceanic anoxic event. Nature Geoscience 10, 129-134.

Xu, W., Ruhl, M., Jenkyns, H. C., Leng, M. J., Huggett, J. M., Minisini, D., Ullmann, C. V., Riding, J. B., Weijers, J. W., Storm, M.S., 2018. Evolution of the Toarcian (Early Jurassic) carbon-cycle and global climatic controls on local sedimentary processes (Cardigan Bay Basin, UK). Earth and Planetary Science Letters 484, 396-411.

Ziegler, P. A., 1992. European Cenozoic rift system. Tectonophysics 208, 91-111.

Manuscript received: June 26, 2020

Revisions required: July 10, 2020

Revised version received: September 11, 2020

Manuscript accepted: September 16, 2020

\section{The pdf version of this paper includes an electronic supplement}

Please save the electronic supplement contained in this pdf-file by clicking the blue frame above. After saving rename the file extension to .zip (for security reasons Adobe does not allow to embed .exe, .zip, .rar etc. files).

\section{Table of contents - Electronic Supplementary Material (ESM)}

Figure 1S: Lithology and carbon and oxygen isotopic trends in the uppermost Pliensbachian and lower Toarcian sediment of the Aubach section. $\delta^{13} \mathrm{C}_{\text {carb }}$ values from the Unterer Stein limestone bed (empty circles) have been excluded from the interpretation because of diagenetic overprint (see main text). Note, that the negative $\mathrm{CIE}$ of $6.3 \%$ develops over four - five steps in $\delta^{13} \mathrm{C}_{\text {org }}$, marked by the red arrows, and of only $4.5 \%$ in $\delta^{13} \mathrm{C}_{\text {carb. }}$.

Table 1S: Labels, $\delta^{13} \mathrm{C}_{\text {org }}$ and $\delta^{13} \mathrm{C}_{\text {carb }}$ values and stratigraphic height $(\mathrm{m})$ of the investigated samples.

Table 2S: Organic matter pyrolysis data with stratigraphic height $(\mathrm{m}) . \mathrm{HI}$ and $\mathrm{OI}$ are presented in $\mathrm{mg}$ $\mathrm{HC} / \mathrm{g} \mathrm{TOC}$ and $\mathrm{mg} \mathrm{CO}_{2} / \mathrm{g}$, respectively.

Table 3S: Element data, total S, total $\mathrm{Fe}, \mathrm{TOC}$ wt $\%, \% \mathrm{CaCO}_{3}$. DOP-T (degree of pyritization based on total $\mathrm{Fe}$ ) have been excluded from the results were TOC $<0.5 \mathrm{wt} \%$ and in the limestone bed (2.90-3.08 m). TOC data in italic are measured using organic matter pyrolysis and the others with the Eltra CS 500 Analyzer. 